
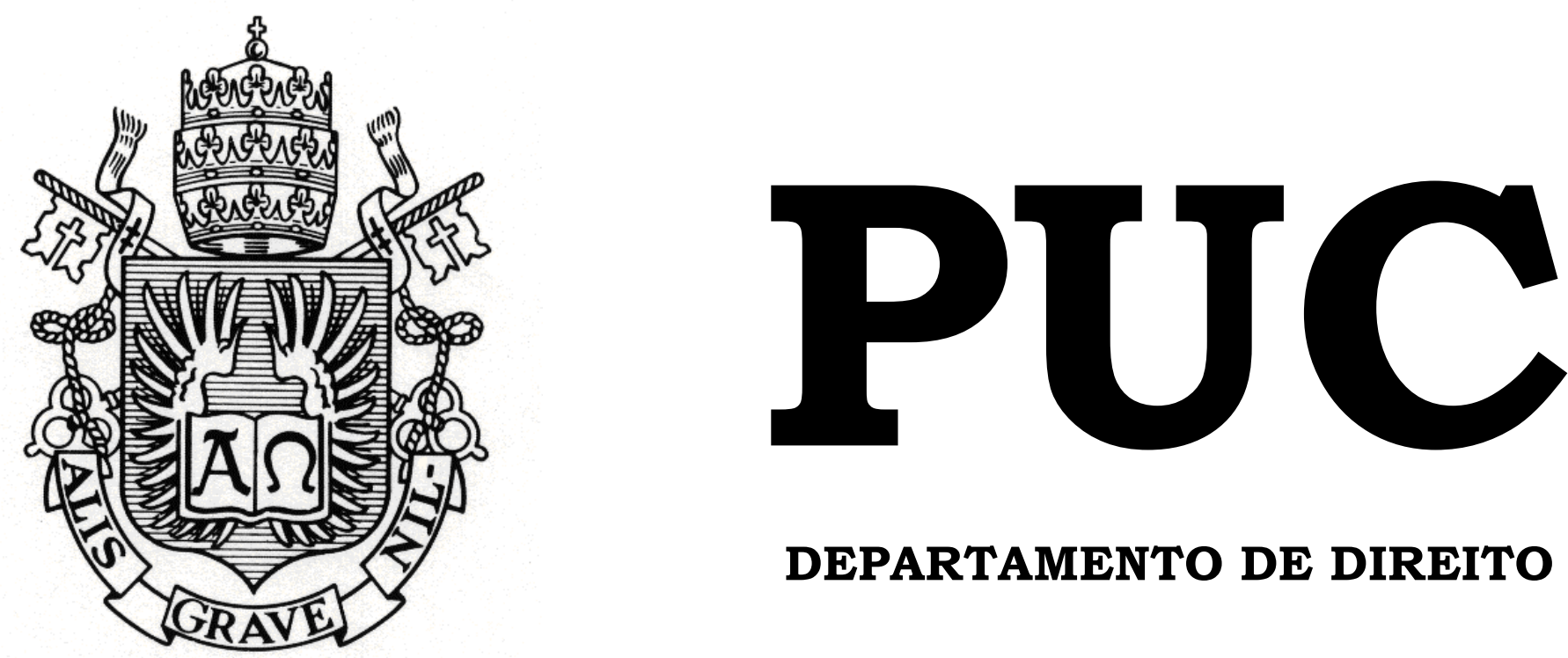

DEPARTAMENTO DE DIREITO

\title{
LIBERDADE DE EXPRESSÃO E DISCURSO DE ÓDIO
}

por

MARIA FERNANDA MOREIRA MARQUES DE OLIVEIRA

ORIENTADOR(A): Leticia da Costa Paes

2013.1

PONTIFÍCIA UNIVERSIDADE CATÓLICA DO RIO DE JANEIRO

RUA MARQUÊS DE SÃO VICENTE, 225 - CEP 22453-900

RIO DE JANEIRO - BRASIL 


\section{LIBERDADE DE EXPRESSÃO E DISCURSO DE ÓDIO}

por

\section{MARIA FERNANDA MOREIRA MARQUES DE OLIVEIRA}

Monografia apresentada ao Departamento de Direito da Pontifícia Universidade Católica do Rio de Janeiro (PUC-Rio) para a obtenção do Título de Bacharel em Direito.

Orientador(a): Leticia da Costa Paes 
Às minhas avós, Norma e Jamile, por me ensinarem o que é o amor e por me mostrarem a força de se lutar pela vida. 
Paz sem voz não é paz, é medo - O Rappa

O que eu quero é ter voz

- Irmã Fátima 


\section{Agradecimentos}

Gostaria de agradecer a todas as pessoas as quais contribuíram, de alguma maneira, para a minha formação acadêmica e, em especial, aos que foram fundamentais na realização dessa monografia. Assim, gostaria de agradecer:

À Leticia Paes, por aceitar a loucura de me orientar, e à Lele, pela amizade e pelo carinho;

A meus pais, Beth e Fernando, e à minha irmã, Bel, pois eu sei que conviver comigo nem sempre é uma tarefa fácil;

À toda a minha família pelo apoio nas horas mais difíceis;

Às minhas amigas de toda a vida, Ana e Livia, pelas risadas gostosas, pelos choros divididos e pelo amor compartilhado;

Aos poucos, mas bons, amigos que a PUC me deu, pelos debates apaixonados, aonde quer que fosse, e pela amizade, em especial a Estela, Pestana, Filipi e Bruna;

À Michelle, meine süße, por me acompanhar desde os tempos de Cruzeiro;

Ao grupo de gênero, por me acolher quando ainda engatinhava e por ter me ensinado a dar os primeiros passos, em especial à professora Márcia, pela oportunidade, à Adriana e à Joanna, por terem me feito entender Butler, e à Maria e à Carol, por dividirem as caras de pânico;

A todos aqueles que conheci no Núcleo de Direitos Humanos, pois, de alguma maneira ou de outra, contribuíram para o meu desenvolvimento acadêmico;

Aos professores que, de alguma maneira, me inspiraram ao longo da faculdade e, em especial, à professora Mariana Trotta, por me mostrar que há um espaço no Direito para mim;

Ao meu querido amigo Luc e ao professor Fábio Leite, por me mostrarem que não sou louca sozinha. 


\section{Resumo}

O presente trabalho desenvolveu-se com o objetivo de apresentar o debate teórico sobre a aparente dicotomia entre liberdade de expressão e discurso de ódio, a partir da perspectiva do mercado livre de ideias. Assim, apresenta a teoria de Stuart Mill, expondo seus argumentos principais para a defesa da livre manifestação de todas as ideias e opiniões. Em seguida são expostas as críticas de Catherine A. MacKinnon a essa liberdade incondicional, especialmente em se tratando de discurso de cunho odioso.

Posteriormente, é demonstrada a maneira que os sistemas europeu e interamericano de proteção aos direitos humanos e as cortes constitucionais do Brasil e dos Estados Unidos lidam com o tema, seja considerando expressões de ódio como limites à liberdade de manifestação, ou como protegidas por ela. Por fim, é feita uma ponderação entre os argumentos apresentados de maneira a se pensar uma luta política, além do direito.

Palavras-chave: liberdade de expressão; discurso de ódio; Stuart Mill; Catherine A. MacKinnon 


\section{Sumário}

Introdução

Capítulo I. Discussão doutrinária sobre suposta polarização entre discurso de ódio e liberdade de expressão

1.1. A livre manifestação como conquista histórica

1.2 Limites à liberdade de expressão

1.3. Discurso de ódio: o debate doutrinário sob a perspectiva de um mercado livre de ideias

1.3.1. O mercado livre de ideias pensado por Stuart Mill

1.3.2. A crítica ao mercado livre de ideias a partir da teoria de Catherine A. MacKinnon

Capítulo II. A solução jurisprudencial das cortes internacionais e do direito comparado

2.1. O Sistema interamericano de proteção aos direitos humanos

2.2. A Corte Européia de Direitos Humanos 36

2.3. Os Estados Unidos da América

41

2.4. A decisão no Supremo Tribunal Federal do Brasil

Capítulo III. A igualdade como pilar do mercado livre de idéias

Conclusão 


\section{Introdução}

O presente trabalho tem como objetivo refletir sobre o tema da liberdade de expressão e do discurso de ódio. A liberdade de expressão é um dos pilares sustentadores de uma democracia, pois permite aos cidadãos, através de um debate livre e aberto, controlarem os atos estatais, sem medo de repressão ao realizaram críticas, e exporem ideias no intuito definirem o modelo de sociedade o qual pretendem construir para si. Portanto, qualquer restrição a tal direito, impedindo a circulação de ideias e de informações, influencia diretamente na forma como a sociedade irá se conduzir, como ocorre com a represália ao discurso de ódio.

Esse ponto gera enorme divergência entre doutrinadores e juristas. De um lado, há os defensores de que o discurso de ódio deve ser protegido como objetivo final de uma proteção à expressão, visto que é exatamente o discurso incômodo e abjeto a própria razão de ser de se garantir a livre manifestação de ideias. De outro, argumenta-se que o discurso odioso, em se tratando de manifestação puramente odiosa e sem contribuição relevante para o desenvolvimento da sociedade, extrapolaria os limites da liberdade de expressão, a qual teria sua garantia quando ligada ao discurso político.

De fato, a liberdade de expressão não é um direito absoluto e está sujeito a limitações, cujas delimitações não se traduzem em tarefa simples. Assim, levando-se em conta, então, a atualidade do tema, sua importância na construção de uma sociedade democrática e a polarização trazida pelo mesmo, faz-se fundamental a problematização da forma como tal questão é abordada na maior parte das cortes constitucionais das sociedades ocidentais e nos sistemas internacionais de proteção aos direitos humanos.

O primeiro capítulo será dedicado à apresentação da discussão doutrinária acerca do tema. Primeiramente, porém, será feita uma análise da liberdade de expressão como uma conquista histórica e, em seguida, do debate teórico acerca do tema, o qual, como acima mencionado, gera enorme 
discussão. Diversos autores se debruçaram sobre essas questões, porém o presente trabalho se limitará a estudaras teorias de Stuart Mill, na defesa de um mercado livre de ideias, e de Catherine A. MacKinnon, a qual apresenta contundentes críticas ao modelo do primeiro.A escolha dos autores se deu em razão de suas particulares importâncias para o tema. Stuart Mill, filósofo inglês liberal do século XIX, foi quem desenvolveu a teoria do mercado livre de ideias, no qual todas as ideias deveriam ser expostas para que os indivíduos e a sociedade pudessem escolher quais as melhores, assim como funciona em um mercado de produtos, no qual o melhor produto torna-se dominante em um mercado. Catherine MacKinnon, contemporânea constitucionalista norteamericana, em contra ponto, identifica problemas, na prática, da teoria de Mill e estrutura uma maneira diferente de se lidar com os problemas reais, especialmente no tocante aos problemas trazidos ou reforçados pelo discurso de ódio.

Apresentado o debate, o capítulo II irá abordar a forma como o discurso de ódio é entendido na jurisprudência de alguns tribunais. Para tanto, será exposta a jurisprudência acerca do tema nos sistemas interamericano e europeu de proteção aos direitos humanos e nas cortes constitucionais do Brasil e dos Estados Unidos. Os sistemas escolhidos assim o foram por motivos determinados. O Brasil é o local aonde vivemos e de onde emanam as normativas mais influentes em nosso cotidiano. Por isso, entender como é tratada a intervenção ao direito à livre manifestação é fundamental para a compreensão dos problemas da realidade que nos cerca. O sistema interamericano, por ser o sistema local de proteção aos direitos humanos do qual o Brasil faz parte, impõe-se como indispensável, visto que diversas conquistas em matéria de direitos humanos, inclusive a liberdade de expressão, só se tornaram possíveis em razão da existência de documentos legais e de órgãos jurisdicionais em âmbito internacional. 
Embora não influenciem diretamente na vida do cidadão brasileiro, o sistema europeu de proteção aos direitos humanos e os Estados Unidos são fundamentais nessa análise. O primeiro, pois é nele, muitas vezes, que os órgãos do sistema interamericano se baseiam para a tomada de decisões, ainda quando é pioneiro em tratar de certos temas, como o próprio discurso de ódio. Já os Estados Unidos se apresentam como indispensáveis a qualquer análise sobre o tema em razão de sua especial proteção à liberdade de expressão. Ao concedê-la uma posição privilegiada no ordenamento jurídico norte-americano, é o único país das sociedades ocidentais que defende, de maneira já consolidada, o discurso de ódio como uma forma de manifestação protegida pelo direito à liberdade de expressão.

Por fim, introduzidos o debate teórico e a divergência jurisprudencial acerca do tema, o capítulo III destina-se a ponderar os argumentos apresentados. Assim, reconhecerá as críticas de MacKinnon, rejeitando, contudo, sua solução e trará formas de se pensar o problema da desigualdade posto pelo discurso de ódio, sem que seja necessária a supressãodas expressões odiosas, as quais, embora desprezíveis, tem na sua manifestação uma das condições basilares de um sistema democrático, qual seja, a de instaurar o debate.

Longe de buscar soluções ou respostas definitivas a essa questão, o presente trabalho destina-se a realizar uma análise introdutória ao tema. Assim, tomando como recorte metodológico o mercado livre de ideias, pretende conduzir a uma reflexão sobre a forma como é abordado o discurso de ódio e apresentar meios a partir dos quais pode o problema ser pensando sem que seja a expressão reprimida, utilizando-a, em sentido contrário, na promoção da igualdade. 


\section{CAPÍTULO 1. DISCUSSÃO DOUTRINÁRIA SOBRE SUPOSTA POLARIZAÇÃO ENTRE DISCURSO DE ÓDIO E LIBERDADE DE EXPRESSÃO}

Você aprendeu o que liberdade significa, e nunca mais se esqueça disso $^{1}$

- Anônimo, no Muro de Berlin

Atualmente, apesar das conquistas sociais e jurídicas em relação ao direito de se expressar, a liberdade de manifestação segue sendo um objetivo a ser alcançado. Em razão das dificuldades de efetivação dessa garantia constitucional, o presente capítulo destina-se a discutir seus limites e, em especial, em que medida o discurso de ódio se encontra ou não abarcado por ela, sob a perspectiva da teoria do mercado livre de ideias.

\subsection{A livre manifestação como conquista histórica}

Os Estados democráticos ocidentais garantem, hoje, a liberdade de expressão como um direito fundamental. Entretanto, uma análise da trajetória dessas sociedades demonstra que tal direito foi historicamente reprimido ${ }^{2}$. O excesso de espontaneidade e de individualidade, de acordo com Stuart Mill, levou à percepção pelos ocupantes do poder da dificuldade de se induzir indivíduos de corpos e de mentes fortes a obedecer a leis as quais requeressem desses o controle de seus impulsos ${ }^{3}$. Encontraram, então, no medo um instrumento eficaz de domínio sobre o indivíduo ${ }^{4}$.

\footnotetext{
1 "Du hast gelernt was Freiheit heißt und dass vergiss nie mehr" (versão original).

${ }^{2}$ LEWIS, Anthony. Freedom for the thought that we hate: a biography of the First Amendment. New York: Basic Books, 2007, p. 122-123.

${ }^{3}$ MILL, John Stuart. On liberty. New York: Dover Publications Inc., 2002, p. 50.

${ }^{4}$ LEWIS, Anthony. Freedom for the thought that we hate: a biography of the First Amendment. New York: Basic Books, 2007, p. 104.
} 
O exercício do poder, segundo Michel Foucault, se dá dentro dos limites de um direito de soberania e de um mecanismo de disciplina ${ }^{5}$, os quais, então, serviram de veículo para a institucionalização do medo ${ }^{6}$. A soberania, ainda que não se limite ao Direito, dele se utiliza. Neste sentido, diversos mecanismos utilizados para reprimir as livres manifestações serviram e servem de alicerce para instaurar, em determinados períodos da nossa história, o medo e o próprio controle da população. A censura, por exemplo, ainda é uma valiosa arma na repressão aos discursos, seja através da criação de monopólios de impressão, da exigência de licenciamento para publicações ou de leis de desacato. Tais medidas mostraram-se bastante eficientes, uma vez que impingiram um profundo clima de temor nos indivíduos. Acabaram, então, por gerar a autocensura e, dessa maneira, silenciaram, não somente o comunicador social, mas toda a sociedade.

No entanto, como toda ação possui uma reação, a autoridade não existiu sem que, de outro lado, houvesse um grupo lutando pela liberdade ${ }^{7}$. Dessa forma, se atentarmos aos diversos movimentos de resistência nas sociedades ocidentais em prol de um direito de se expressar livremente, será possível perceber que tais movimentos surgiram com um viés político e objetivavam, em sua origem, como afirmou Frederick Schauer, a crítica ao Estado. Isto é, o direito dos cidadãos de criticar e talvez, até mesmo, insultar o monarca, o governo e os funcionários do Estado ${ }^{8}$.

\footnotetext{
${ }^{5} \mathrm{O}$ âmbito disciplinar, embora tenha sido o foco principal de análise do referido autor, é tema bastante complexo e sua apropriada abordagem enseja um novo trabalho. Dessa maneira, não será, aqui, objeto de estudo.

${ }^{6}$ FOUCAULT, Michel. Microfísica do poder. $25^{\text {a }}$ ed. São Paulo: Graal, 2012, p. 292-293.

${ }^{7}$ MILL, John Stuart. On liberty. New York: Dover Publications Inc., 2002, p. 1.

${ }^{8}$ SCHAUER, Frederick. Facts and the First Amendment. UCLA Law Review, n. 897, 2010, p. $903-$ 904.
} 
Assim sendo, a liberdade de expressão, através da garantia de proteção à exposição dos abusos de poder, vem como uma forma de fortalecer os indivíduos perante as tiranias ${ }^{9}$. Nas palavras de Stuart Mill:

Por liberdade, foi entendida a proteção contra a tirania dos governantes políticos, os quais foram concebidos (...) como em uma posição necessariamente antagônica ao povo a quem governava. (...) Seu poder era considerado necessário, mas altamente perigoso, como uma arma que tentariam usar contra seus súditos, assim como contra os inimigos externos ${ }^{10}$.

Em analogia ao que afirma a feminista americana Catherine A. MacKinnon sobre a conquista de direitos, então, entende-se a repressão à liberdade como "uma história épica de superação, de ter certeza de que isso nunca aconteça novamente" ${ }^{\prime 1}$. De tal modo, passou-se a apreciar a liberdade de expressão como arma fundamental do indivíduo na luta pela garantia de uma vida livre de opressão.

Porém, uma questão se impõe: o que é liberdade de expressão? Em um primeiro momento, será tal pergunta abordada a partir de um caráter positivo desse princípio fundamental e, somente no tópico seguinte, será analisada a partir de uma perspectiva negativa, com a discussão sobre seus limites.

Tendo-se em vista a vasta jurisprudência da Corte Interamericana de Direitos Humanos e sua fundamental importância em matéria de liberdade de expressão, será adotado o seu entendimento sobre o tema. Como afirmado pela Corte, a liberdade de expressão engloba tanto um direito ativo à liberdade de manifestação e de pensamento de ideias, quanto um direito passivo de recebêlas. Isso significa dizer que:

[N]ão só têm os indivíduos o direito e a liberdade de expressar seus próprios pensamentos, mas também o direito e a liberdade de buscar, receber e difundir informações e ideias de todos os tipos, visto que o controle efetivo dos cidadãos sobre as ações públicas requer no só uma

\footnotetext{
${ }^{9}$ HEYMAN, Steven J. Righting the balance: an inquiry into the foundations and limits of freedom of speech. In: AMAR, Vikram David (Org). The First Amendment Freedom of Speech: its constitutional history and the contemporary debate. New York: Prometheus Books, 2009, p. 36.

${ }^{10}$ MILL, John Stuart. On liberty. New York: Dover Publications Inc., 2002, p. 1.

${ }^{11}$ MACKINNON, Catherine. Only words. Cambridge: Harvard University Press, 1996, p. 74-75.
} 
abstenção por parte do Estado de censurar informação como também requer a ação positiva de proporcioná-la aos cidadãos. Assim, quando a liberdade de expressão de um indivíduo é restringida de forma ilegal, não é apenas o direito do indivíduo está sendo violado, mas também o direito de todos os outros de "receber" informações e ideias ${ }^{12}$.

A partir desse conceito de liberdade de expressão, pode-se perceber que esta adquire duas dimensões: uma individual e uma coletiva. A sua dimensão individual, de acordo com Roberto Cuéllar, é o direito de expressar suas próprias ideias, enquanto a dimensão social envolve o direito de receber informações, estando aqui incluído também o direito de conhecer as ideias dos demais $^{13}$. Portanto, apresenta-se fundamental a garantia de tal direito no desenvolvimento tanto da personalidade do indivíduo, quanto de uma sociedade democrática ${ }^{14}$.

Em função dessa dupla importância, a liberdade de expressão foi positivada em documentos jurídicos tanto internacionais, como nacionais, sendo amplamente assegurada não só nos Tratados e nas Declarações de Direitos Humanos, como também nas Constituições de diversos países ${ }^{15}$. Conforme explica José Afonso da Silva, as declarações de direitos, as quais assumiram, inicialmente, a forma de proclamações solenes enunciadoras de direitos, passaram a constituir o preâmbulo de Constituições estaduais ${ }^{16}$.

Assim, passa-se a uma breve exposição das normativas as quais realizaram a positivação acima afirmada. Antes, porém, ressalte-se que, em razão da necessidade de recorte metodológico, como afirmado na introdução do presente trabalho, só serão analisados, no âmbito internacional, os sistemas

\footnotetext{
${ }^{12}$ Corte IDH. La colegación obligatória de periodistas. Opinião Consultiva OC-5/85, de 13 de novembro de 1985, par. 30 .

${ }^{13}$ CUÉLLAR, Roberto. Presentación. In: IIDH. Libertad de expresión en las Américas. Los cinco primeros informes de la Relatoría para la Libertad de Expresión. San José: Instituto Interamericano de Derechos Humanos, 2003, p. 13.

${ }^{14}$ CUÉLLAR, Roberto. Presentación. In: IIDH. Libertad de expresión en las Américas. Los cinco primeros informes de la Relatoría para la Libertad de Expresión. San José: Instituto Interamericano de Derechos Humanos, 2003, p. 14.

${ }^{15}$ MEYER-PFLUG, Samantha Ribeiro. Liberdade de expressão e discurso do ódio. Sāo Paulo: Editora Revista dos Tribunais, 2009, p. 27.
} 
interamericano e europeu de proteção aos direitos humanos e, no âmbito do direito comparado, os Estados Unidos e o Brasil.

A Organização dos Estados Americanos (OEA) não se limitou a garantir a liberdade de expressão em apenas um documento jurídico. Em seu âmbito, encontra-se tal direito afirmado na Declaração Americana dos Direitos e Deveres do Homem ${ }^{17}$, na Convenção Americana sobre Direitos Humanos ${ }^{18}$ e na Declaração de Princípios sobre Liberdade de Expressão ${ }^{19}$. A primeira Declaração afirma, logo em seu artigo I, que "todo ser humano tem direito à vida, à liberdade e à segurança de sua pessoa", garantindo, mais especificamente, a liberdade de investigação, de opinião, de expressão e de difusão do pensamento em seu artigo IV $^{20}$. A Convenção Americana estabeleceu, em seu artigo 13, a liberdade de pensamento e de expressão ${ }^{21}$. E, por fim, a Declaração de Princípios sobre Liberdade de Expressão, por considerar que "a liberdade de expressão não é uma concessão dos Estados, e

${ }^{16}$ SILVA, José Afonso da. Curso de Direito Constitucional positivo. $32^{\text {a }}$ ed. São Paulo: Malheiros Editores, 2009, p. 175.

${ }^{17}$ OEA. Declaração Americana dos Direitos e Deveres do Homem. IX Conferência Internacional Americana, Bogotá, 1948.

${ }^{18}$ OEA. Convenção Americana sobre Direitos Humanos. Conferência Especializada Interamericana sobre Direitos Humanos, San José, Costa Rica, 22 nov. 1969.

${ }^{19}$ CIDH. Declaração de Princípios sobre Liberdade de Expressão. $108^{\circ}$ período ordinário de sessões, 16-27 out. 2000.

${ }^{20}$ Artigo IV. Toda pessoa tem direito à liberdade de investigação, de opinião e de expressão e difusão do pensamento, por qualquer meio. In: OEA. Declaração Americana dos Direitos e Deveres do Homem. IX Conferência Internacional Americana, Bogotá, 1948.

${ }^{21}$ Artigo 13. Liberdade de pensamento e de expressão. (1) Toda pessoa tem direito à liberdade de pensamento e de expressão. Esse direito compreende a liberdade de buscar, receber e difundir informações e idéias de toda natureza, sem consideração de fronteiras, verbalmente ou por escrito, ou em forma impressa ou artística, ou por qualquer outro processo de sua escolha; (2) O exercício do direito previsto no inciso precedente não pode estar sujeito a censura prévia, mas a responsabilidades ulteriores, que devem ser expressamente fixadas pela lei e ser necessárias para assegurar: (a) o respeito aos direitos ou à reputação das demais pessoas; ou (b) a proteção da segurança nacional, da ordem pública, ou da saúde ou da moral públicas; (3) Não se pode restringir o direito de expressão por vias ou meios indiretos, tais como o abuso de controles oficiais ou particulares de papel de imprensa, de frequiências radioelétricas ou de equipamentos e aparelhos usados na difusão de informação, nem por quaisquer outros meios destinados a obstar a comunicação e a circulação de idéias e opiniões; (4) A lei pode submeter os espetáculos públicos a censura prévia, com o objetivo exclusivo de regular o acesso a eles, para proteção moral da infância e da adolescência, sem prejuízo do disposto no inciso 2; e (5) A lei deve proibir toda propaganda a favor da guerra, bem como toda apologia ao ódio nacional, racial ou religioso que constitua incitação à discriminação, à hostilidade, ao crime ou à violência. In: 
sim, um direito fundamental”22, foi inteiramente dedicada à proteção desse direito. A União Européia (UE), por sua vez, inscreveu na Convenção Européia dos Direitos do Homem ${ }^{23}$ e na Carta dos Direitos Fundamentais da União Européia ${ }^{24}$ a liberdade de expressão como direito fundamental. Em ambos os documentos tal garantia foi afirmada no $10^{\circ} \operatorname{artigo~}^{25}$, tendo, porém, a Carta se estendido até o artigo seguinte ${ }^{26}$.

A Constituição norte-americana foi a pioneira a tratar do tema. Em sua Primeira Emenda, inserida no texto constitucional através da Carta de Direitos ("Bill of Rights"), ratificada em 1788, conferiu uma posição privilegiada de tal princípio e impôs que:

O congresso não deve fazer leis a respeito de se estabelecer uma religião, ou proibir das mesmas; ou diminuir a liberdade de expressão, ou da imprensa; ou sobre o direito das pessoas de se reunirem

OEA. Convenção Americana sobre Direitos Humanos. Conferência Especializada Interamericana sobre Direitos Humanos, San José, Costa Rica, 22 nov. 1969.

${ }^{22}$ Preâmbulo. CIDH. Declaração de Princípios sobre Liberdade de Expressão. $108^{\circ}$ período ordinário de sessões, 16-27 out. 2000.

${ }^{23}$ UE. Convenção Européia dos Direitos do Homem. Roma, 4 nov. 1950.

${ }^{24}$ UE. Carta dos Direitos Fundamentais da União Européia. Nice, dez./2000.

${ }^{25}$ Artigo $10^{\circ}$. (1) Qualquer pessoa tem direito a liberdade de expressão. Este direito compreende a liberdade de opinião e a liberdade de receber ou de transmitir informações ou ideais sem que possa haver ingerência de quaisquer autoridades públicas e sem considerações de fronteiras. O presente artigo não impede que os estados submetam as empresas de radiodifusão, de cinematografia ou de televisão a um regime de autorização prévia; (2) O exercício destas liberdades, porquanto implica deveres e responsabilidades, pode ser submetido a certas formalidades, condições, restrições ou sanções, previstas pela lei, que constituam providencias necessárias, numa sociedade democrática, para a segurança nacional, a integridade territorial ou a segurança pública, a defesa da ordem e a prevenção do crime, a protecção da saúde ou da moral, a protecção de honra ou dos direitos de outrem, para impedir a divulgação de informações confidenciais, ou para garantir a autoridade e a imparcialidade do Poder Judicial. In: UE. Convenção Européia dos Direitos do Homem. Roma, 4 nov. 1950.

Artigo $10^{\circ}$. Liberdade de pensamento, de consciência e de religião. (1) Todas as pessoas têm direito à liberdade de pensamento, de consciência e de religião. Este direito implica a liberdade de mudar de religião ou de convicção, bem como a liberdade de manifestar a sua religião ou a sua convicção, individual ou colectivamente, em público ou em privado, através do culto, do ensino, de práticas e da celebração de ritos; (2) $\mathrm{O}$ direito à objecção de consciência é reconhecido pelas legislações nacionais que regem o respectivo exercício. In: UE. Carta dos Direitos Fundamentais da União Européia. Nice, dez./2000.

${ }^{26}$ Artigo $11^{\circ}$. Liberdade de expressão e de informação. (1) Qualquer pessoa tem direito à liberdade de expressão. Este direito compreende a liberdade de opinião e a liberdade de receber e de transmitir informações ou ideias, sem que possa haver ingerência de quaisquer poderes públicos e sem consideração de fronteiras. (2) São respeitados a liberdade e o pluralismo dos meios de comunicação social. In: UE. Carta dos Direitos Fundamentais da União Européia. Nice, dez./2000. 
pacificamente, e de fazerem pedidos ao governo para que sejam feitas reparações por ofensas ${ }^{27}$.

A Constituição da República Federativa do Brasil de 1988 também conferiu status constitucional à liberdade de expressão. Ao contrário dos documentos jurídicos acima apontados, o sistema brasileiro, como bem afirmou Daniel Sarmento, na tentativa de "exorcizar os fantasmas do regime militar,"28, acabou por destinar diversos dispositivos à proteção desse direito. Assim sendo, é encontrado tanto nos incisos IV, IX e XIV do artigo $5^{\circ}$, quanto no caput e nos parágrafos $1^{\circ}$ e $2^{\circ}$ do artigo $220^{29}$. Tais dispositivos regem, respectivamente, a "liberdade de manifestação do pensamento"; a "liberdade de expressão de atividade intelectual, artística, científica e de comunicação, independentemente de censura ou licença"; o direito à informação e garantia do sigilo da fonte jornalística; a "manifestação do pensamento, da criação, da expressão e informação", sob qualquer forma e veículo; a "liberdade de informação jornalística em qualquer veículo de comunicação social" e a proibição de "qualquer censura de natureza política, ideológica e artística".

Garantido juridicamente, o problema que se apresenta em relação a esse direito é a sua delimitação negativa, isto é, seus limites. Sabe-se que a

\footnotetext{
${ }^{27}$ USA. Constitution of the United States of America. Amendment I. Congress shall make no law respecting an establishment of religion, or prohibiting the free exercise thereof; or abridging the freedom of speech, or of the press; or the right of the people peaceably to assemble, and to petition the government for a redress of grievances In: AMAR, Vikram David (Org). The First Amendment Freedom of Speech: its constitutional history and the contemporary debate. New York: Prometheus Books, 2009, p. 295.

${ }^{28}$ SARMENTO, Daniel. A liberdade de expressão e o problema do hate speech. Revista de Direito do Estado. Rio de Janeiro: Renovar, 2006, p. 53-106.

${ }^{29}$ Artigo $5^{\circ}$. Todos são iguais perante a lei, sem distinção de qualquer natureza, garantindo-se aos brasileiros e aos estrangeiros residentes no País a inviolabilidade do direito à vida, à liberdade, à igualdade, à segurança e à propriedade, nos termos seguintes: (...) IV - é livre a manifestação do pensamento, sendo vedado o anonimato; (...) IX - é livre a expressão da atividade intelectual, artística, científica e de comunicação, independentemente de censura ou licença; (...) XIV - é assegurado a todos $\mathrm{o}$ acesso à informação e resguardado o sigilo da fonte, quando necessário ao exercício profissional. Artigo 220. A manifestação do pensamento, a criação, a expressão e a informação, sob qualquer forma, processo ou veículo não sofrerão qualquer restrição, observado o disposto nesta Constituição. $\S 1^{\circ}$ Nenhuma lei conterá dispositivo que possa constituir embaraço à plena liberdade de informação jornalística em qualquer veículo de comunicação social, observado o disposto no art. $5^{\circ}, \mathrm{IV}, \mathrm{V}, \mathrm{X}, \mathrm{XIII}$ e XIV; $\S 2^{\circ}$ - É vedada toda e qualquer censura de natureza política, ideológica e artística. In: BRASIL. Constituição da República Federativa do Brasil. Brasília, 5 out. 1988.
} 
liberdade de expressão não é um direito absoluto ${ }^{30}$, estando sujeita a restrições. Portanto, sua mera garantia em documentos legais não esgota o assunto, fazendo-se necessária a transgressão da esfera legislativa, com a participação da doutrina e da jurisprudência. É o que se passa a analisar.

\subsection{Limites à liberdade de expressão}

Vista a abordagem legal da liberdade de expressão, o que se passa a investigar é o limite doutrinário a tal direito. Primeiramente, será feita uma breve consideração acerca de manifestações consideradas fora do escopo da liberdade de expressão as quais provocam pouca discussão nos dias atuais. Em seguida, serão apresentados discursos cuja inclusão, ou não, no âmbito de proteção desse princípio constitucional gera uma maior divergência.

Quando uma manifestação é susceptível de constituir uma iniciativa positiva capaz de realizar um ato malicioso, perde ela a sua imunidade, afirma Stuart Mill ${ }^{31}$. Porém, questiona Anthony Lewis ${ }^{32}$, “[o]nde deve ser traçada a linha entre a liberdade e a ordem?". À essa pergunta não há uma resposta pronta. A doutrina vem se esforçando para, ao longo das transformações sociais, determinar quais expressões estão inseridas no âmbito de proteção da liberdade de expressão, e quais encontram-se fora dele.

Determinados discursos, afirma Geoffrey Stone, possuem baixo valor social e, por isso, podem mais facilmente ser limitados, não se encontrando abarcados pela liberdade de expressão. O referido autor lista algumas dessas manifestações: incitação a crime, falso testemunho, obscenidade e pornografia infantil ${ }^{33}$. Em suas palavras:

\footnotetext{
${ }^{30}$ MILL, John Stuart. On liberty. New York: Dover Publications Inc., 2002, p. 10.

${ }^{31}$ MILL, John Stuart. On liberty. New York: Dover Publications Inc., 2002, p. 46.

${ }^{32}$ LEWIS, Anthony. Freedom for the thought that we hate: a biography of the First Amendment. New York: Basic Books, 2007, p. xi.

${ }^{33}$ STONE, Geoffrey R. Scope of the First Amendment. In. AMAR, Vikram David (Org). The First Amendment Freedom of Speech: its constitutional history and the contemporary debate. New York: Prometheus Books, 2009, p. 155.
} 
[i]ncitação, por exemplo, pode ser suprimida se for direcionada a incitar ou produzir ação ilegal iminente (...). Discurso comercial, por outro lado, pode ser suprimido, se for falso ou enganoso (...). [O]bscenidade, talvez a classe menos protegida das expressão de baixo valor, pode ser suprimida sempre que houver uma intencionalidade complacente ${ }^{34}$.

Entretanto, outras formas de discurso, em razão de seu alto valor social, geram um maior debate. É o caso, por exemplo, de manifestações críticas sobre determinada pessoa. Nesses casos, as discussões giram em torno da tênue linha entre direito da personalidade ${ }^{35}$ e liberdade de expressão. Outro exemplo é o discurso de ódio. Em que medida estão as manifestações odiosas protegidas pela liberdade de expressão? São elas discursos políticos? O primeiro exemplo é demasiado complexo e foge ao escopo do presente trabalho, cujo objeto central é o debate sobre o segundo. Assim sendo, passa-se à análise do debate doutrinário sobre a inclusão, ou não, do discurso de ódio na proteção da liberdade de expressão.

\subsection{Discurso de ódio: o debate doutrinário sob a perspectiva de um mercado livre de ideias}

Em seguida, será apresentado o debate sobre o discurso de ódio. Para tanto, será dado o enfoque a partir da noção do mercado livre de ideias, pensado por Stuart Mill. Em contra partida, serão apresentadas, a partir das análises de Catherine A. MacKinnon, algumas das críticas a esse modelo ${ }^{36}$. Antes, porém, faz-se fundamental determinar o conceito de discurso de ódio.

Tal conceito é de difícil precisão. Apesar do longo debate travado acerca de sua definição, será, para os fins do presente trabalho, adotado o entendimento geral de que se trata de manifestação discriminatória, baseando-

\footnotetext{
${ }^{34}$ STONE, Geoffrey R. Scope of the First Amendment. In. AMAR, Vikram David (Org). The First Amendment Freedom of Speech: its constitutional history and the contemporary debate. New York: Prometheus Books, 2009, p. 156.

${ }^{35}$ Entendidos aqui como os dispostos no inciso $\mathrm{X}$ do artigo $5^{\circ}$ da CRFB/88, quais sejam: intimidade, vida privada, honra e imagem. In: BRASIL. Constituição da República Federativa do Brasil. Brasília, 5 out. 1988 .
} 
se em uma hierarquia social a fim de reforçar tais desigualdades. Nesse sentido, Catherine A. MacKinnon afirma ser a prática social no intuito de "colocar alguém em uma posição desigual ou em uma posição de perda de potência" ${ }^{37}$, através do preconceito ${ }^{38}$.

Assim, pode ser entendido como qualquer manifestação de cunho odioso dirigido a um grupo social, tendo tal manifestação sido proferida exatamente em razão da diferença do grupo ofendido. Pode-se dar tanto em forma de fala, quanto de ação, desde que não constitua crime ou incitação a crime, como bem definiu Raoul Vaneigem ${ }^{39}$ :

[F]az-se mister ressaltar que o direito de tudo dizer, de tudo escrever, de tudo pensar, de tudo ver e ouvir decorre de uma exigência prévia, segundo a qual não existe nem direito nem liberdade de matar, de torturar, de maltratar, de oprimir, de constranger, de privar de alimento, de explorar.

A partir do momento em que o discurso odioso se constitui em ação legalmente vedada, sai do conceito de discurso, passando a ser qualificado como crime. Dessa maneira, percebe-se que não apenas declarações expressas estão incluídas nesse conceito, mas também, por exemplo, uma passeata nazista $^{40}$ ou a queima de uma bandeira ${ }^{41}$, as quais são consideradas discursos odiosos em forma de ação.

Essa forma de discurso retoma a discussão sobre os limites da liberdade de expressão. Há uma forte divergência teórica sobre a forma como tal discurso deve ser abordado. De um lado, defende-se, com base no mercado

\footnotetext{
${ }^{36}$ Uma vez que a liberdade de expressão é um tema interdisciplinar, não estando restrita sua abordagem ao campo do Direito, foi escolhido o recorte metodológico da teoria do mercado livre de ideias de Stuart Mill em razão, além de sua importância histórica, de seu caráter filosófico.

${ }^{37}$ MACKINNON, Catherine. Are women human? And other international dialogues. Cambridge: Harvard University Press, 2007, p. 89.

${ }^{38}$ MACKINNON, Catherine. Only words. Cambridge: Harvard University Press, 1996, p. 99.

${ }^{39}$ VANEIGEM, Raoul. Nada é sagrado, tudo pode ser dito: reflexões sobre a liberdade de expressão. São Paulo: Parábola Editorial, 2004, p. 20.

${ }^{40}$ Supreme Court of the United States. Smith v. Collin, 439 U.S. 916. (1978). Sentença em 16 de outubro de 1978.

${ }^{41}$ Supreme Court of the United States. Texas v. Johnson, 491 U.S. 397 (1989). Sentença em 21 de março de 1989.
} 
livre de ideias, que deve ser protegido como liberdade de expressão. De outro, entende-se se tratar de abuso da mesma. É o que se passa a analisar.

\subsubsection{O mercado livre de ideias pensado por Stuart Mill}

Em relação ao debate sobre os limites da liberdade de expressão, o discurso de ódio figura como peça fundamental. De um lado, há quem defenda a sua liberdade de ser exprimido. De outro, há quem lhe negue vez de ser proferido. Primeiramente, será analisada a defesa da liberdade baseada no funcionamento de um mercado livre de ideias, a partir da teoria de Stuart Mill. Em um segundo momento, teoria de Catherine A. MacKinnon será apresentada como um contra ponto à primeira.

Profundo defensor das liberdades, John Stuart Mill, filósofo e economista inglês do século XIX, via na expressão o veículo pelo qual o indivíduo poderia de fortalecer e as sociedades avançar. De acordo com ele, a insistência de um debate livre e aberto é um obstáculo ao desenvolvimento tanto do indivíduo, quanto da sociedade. Em suas palavras:

Nossa intolerância meramente social não mata ninguém, não acaba com opiniões, mas induz os homens a disfarçá-las, ou a abster-se de qualquer esforço ativo para sua difusão. Com a gente, as opiniões heréticas não ganham perceptivelmente, ou mesmo perdem, espaço a cada década ou geração; elas nunca vislumbram o longe, mas continuam a arder nos círculos estreitos de pensamento e de pessoas estudiosas, entre as quais se originam, sem iluminação, os assuntos gerais da humanidade ou com uma verdade ou uma luz enganosa. E assim é mantido um estado de coisas muito satisfatório para algumas mentes, pois, sem o desagradável processo de multar ou de prender ninguém, ele mantém todas as opiniões aparentemente predominantes imperturbável, enquanto não faz absolutamente interdito o exercício da razão por dissidentes aflitos com a doença do pensamento. (...) Mas o preço pago por esse tipo de pacificação intelectual, é o sacrifício de toda a coragem moral da mente humana ${ }^{42}$.

Nesse sentido, Daniel Sarmento reforça que "um debate livre, robusto e aberto de ideias na sociedade é um dos objetivos fundamentais da liberdade de expressão". E, embora alguns fatalmente saiam arranhados, prossegue o autor, "[e]ste é um preço que vale a pena pagar para viver-se numa democracia"43, pois,

\footnotetext{
${ }^{42}$ MILL, John Stuart. On liberty. New York: Dover Publications Inc., 2002, p. 27.

${ }^{43}$ SARMENTO, Daniel. A liberdade de expressão e o problema do hate speech. Revista de Direito do Estado. Rio de Janeiro: Renovar, 2006, p. 53-106.
} 
explica Raoul Vaneigem, "nada é mais apreciável que a liberdade de palavra concedida a todos, a fim de que um buquê de novas ideias presida à reconstrução da existência individual e da sociedade ${ }^{, 44}$. Por isso, afirma Raoul Vaneigem, “[n]enhuma ideia, nenhum propósito, nenhuma crença devem escapar à crítica, à derrisão, ao ridículo, ao humor, à paródia, à caricatura, à simulação ${ }^{45}$.

Assim, Stuart Mill desenvolveu a teoria, especialmente em seu livro On Liberty, publicado em 1859, de que tal debate se daria em uma forma de mercado livre de ideias ${ }^{46}$. Neste, todas as idéias devem ser apresentadas para que a sociedade possa decidir, a partir do maior número de informações possíveis, o que é melhor para si, não logrando a humanidade justificativa para silenciar determinada pessoa, tendo-se por base o fato de que esta seja a única a ter uma opinião específica ${ }^{47}$. Explicita Raoul Vaneigem

Autorizem-se todas as opiniões; nós saberemos reconhecer as nossas, nós aprenderemos a anular a força atrativa dos males, a impedir que a corrupção do lucro e do poder insista em gangrenar as mentalidades, nós a combateremos pela única crítica que pode erradicá-las: pensando por nós mesmos, deixando de nos manter em dependência, descobrindo, segundo nossos desejos, que existência queremos ter, criando situações que impossibilitem o império da desumanidade ${ }^{48}$.

Deste modo, o mercado livre de ideias possui quatro objetivos principais, a serem analisados a seguir: (i) a busca pela verdade; (ii) o fortalecimento da democracia e do autogoverno; (iii) a autonomia e o livre desenvolvimento da personalidade; e (iv) a realização de uma comunidade mais tolerante e, portanto, mais flexível.

Quanto à busca pela verdade, Stuart Mill afirma haver três motivos principais para a preservação da manifestação de todas as ideias. Em primeiro lugar, a opinião

\footnotetext{
${ }^{44}$ VANEIGEM, Raoul. Nada é sagrado, tudo pode ser dito: reflexões sobre a liberdade de expressão. São Paulo: Parábola Editorial, 2004, p. 54.

${ }^{45}$ VANEIGEM, Raoul. Nada é sagrado, tudo pode ser dito: reflexões sobre a liberdade de expressão. São Paulo: Parábola Editorial, 2004, p. 22.

${ }^{46}$ SUNSTEIN, Cass R. Free speech now. In. AMAR, Vikram David (Org). The First Amendment Freedom of Speech: its constitutional history and the contemporary debate. New York: Prometheus Books, 2009, p. 107.

${ }^{47}$ MILL, John Stuart. On liberty. New York: Dover Publications Inc., 2002, p. 14.

${ }^{48}$ VANEIGEM, Raoul. Nada é sagrado, tudo pode ser dito: reflexões sobre a liberdade de expressão. São Paulo: Parábola Editorial, 2004, p. 99.
} 
que se suprime pode ser a verdadeira. De acordo com o autor, "[a]queles que desejam suprimi-la, é claro, negam sua verdade, mas eles não são infalíveis (...) [e] recusar a audição de uma opinião, por ter certeza de ser esta falsa, é assumir que a sua certeza é a certeza absoluta ${ }^{49}$. Em segundo lugar, a opinião reprimida pode ser falsa. Nesses casos, ainda assim, defende o autor, tal ideia deve integrar o mercado livre, pois, "por mais verdadeira que seja [uma ideia], se não for totalmente, e sem medo, discutida será realizada como um dogma morto, não como uma verdade viva" ${ }^{\text {. }}$. Afirma, ainda, que "a verdade ganha mais com erros de alguém do que quando, com o devido estudo e preparo, pensa por si mesma"51. Em terceiro e último lugar, pode-se ter a situação em que as ideias em conflito, reprimida e repressora, compartilham a verdade entre si e, portanto, é através do debate que se conseguirá descobrir a verdade que há em cada uma ${ }^{52}$.

Quanto ao fortalecimento da democracia e do autogoverno, Stuart Mill entende ser a liberdade de expressão o principal fundamente de uma democracia, pois investe o povo do poder de lutar contra as tiranias, como já afirmado no tópico 1.1 do presente trabalho. Alexander Meiklejohn reforça essa ideia:

$\mathrm{Na}$ minha opinião, as pessoas precisam de liberdade de expressão, porque elas decidiram, em adotar, manter e interpretar a sua Constituição para governar a si mesmas, ao invés de serem governadas por outros. (...) Eu acredito, como professor, que o povo precisa de novelas e de dramas e de pinturas e de poemas, porque eles serão chamados a votar. $\mathrm{O}$ fato social primário que bloqueia e impede o sucesso da nossa experiência de auto-governo é que os nossos cidadãos não são educados para o auto-governo. Estamos aterrorizados com idéias, ao invés de desafiados e estimulados por eles. Nosso humor dominante não é a coragem das pessoas que se atrevem a pensar. É a timidez de quem teme e odeia quando as convenções são questionados 53 .

Quanto à autonomia dos indivíduos, defende Stuart Mill existir duas importâncias pontuais do mercado livre de ideias: (a) o desenvolvimento da individualidade; e (b) o fortalecimento das mentes humanas. Em relação ao

\footnotetext{
${ }^{49}$ MILL, John Stuart. On liberty. New York: Dover Publications Inc., 2002, p. 14-15.

${ }^{50}$ MILL, John Stuart. On liberty. New York: Dover Publications Inc., 2002, p. 29.

${ }^{51}$ MILL, John Stuart. On liberty. New York: Dover Publications Inc., 2002, p. 28.

${ }_{53}^{52}$ MILL, John Stuart. On liberty. New York: Dover Publications Inc., 2002, p. 38.

${ }^{53}$ MEIKLEJOHN, Alexander. The First Amendment is an absolute. In. AMAR, Vikram David (Org). The First Amendment Freedom of Speech: its constitutional history and the contemporary debate. New York: Prometheus Books, 2009, p. 140.
} 
desenvolvimento da individualidade, alega que "[n]ão há razão para que todas as existências humanas devam ser construídas em um, ou em um pequeno número de padrões”. Ou seja, "[s]e uma pessoa possui quantidade tolerável de bom senso e experiência, seu próprio modo de expor a sua existência é o melhor modo, não por ser o melhor em si, mas sim, porque é o seu próprio modo" ${ }^{54}$. Já em relação ao fortalecimento das mentes humanas, entende que os seres humanos devem ser incentivados a distinguir entre o melhor e o pior, sendo estimulados, sempre que possível, a escolher o primeiro e evitar o segundo. É a necessidade de se considerar e de se refletir sobre as opções disponíveis que fortalece a mente humana ${ }^{55}$ : “[a] natureza humana não é como uma máquina a ser construída a partir de um modelo (...), mas sim, como uma árvore, a ser desenvolvida conforme a tendência das forças internas que a tornam a viva" ${ }^{, 56}$. Raoul Vaneigem explica:

Aceitar que tudo seja dito, que nada seja encoberto pelo véu do silencia, é aprender, ao mesmo tempo, a separar, a selecionar, a decodificar, a criticar, a não cair na dependência de uma encenação espetacular em que as facções intercambiáveis do bem e do mal obedecem às manipulações dos lobbies internacionais. Visto que nenhuma informação deve ser ocultada, é preciso preparar a criança para discernir o que a informação dissimulada, o que ela provoca voluntária ou involuntariamente, o que, enfim, encontra seu uso na prática da felicidade e da generosidade afetiva ${ }^{57}$.

Quanto ao último objetivo do mercado livre de idéias a ser exposto no presente trabalho, a realização de uma sociedade mais tolerante, Raoul Vaneigem explica que "a defesa da liberdade é um ataque à hipocrisia de uma sociedade que, por não conseguir extinguir as causas da suas desventuras, opta sempre por esconder os próprios males de si mesma" 58 . E mais, Anthony Lewis afirma que "[o]s cidadãos de uma sociedade livre devem ter a coragem (...) de ouvir não só o discurso político indesejável, mas também as ideias novas e chocantes da ciência e das artes"

\footnotetext{
${ }^{54}$ MILL, John Stuart. On liberty. New York: Dover Publications Inc., 2002, p. 56.

${ }_{55}^{55}$ MILL, John Stuart. On liberty. New York: Dover Publications Inc., 2002, p. 64-66.

${ }_{57}^{56}$ MILL, John Stuart. On liberty. New York: Dover Publications Inc., 2002, p. 49.

${ }^{57}$ VANEIGEM, Raoul. Nada é sagrado, tudo pode ser dito: reflexões sobre a liberdade de expressão. São Paulo: Parábola Editorial, 2004, p. 94 e 95.

${ }^{58}$ VANEIGEM, Raoul. Nada é sagrado, tudo pode ser dito: reflexões sobre a liberdade de expressão. São Paulo: Parábola Editorial, 2004, p. 8.

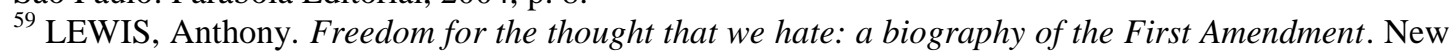
York: Basic Books, 2007, p. 186.
} 
Assim, torna-se fundamental à existência própria de uma sociedade democrática, aprender a tolerar o desagradável, o prejudicial, o ofensivo ${ }^{60}$.

A partir de todo o acima exposto, percebe-se que, para os defensores de um mercado livre de ideias, o discurso de ódio não deve ser impedido de ser proferido. Entendendo-se que, como afirma Raoul Vaneigem ${ }^{61}$, "[t]olerar todas as ideias não é aprová-las", o discurso de ódio é fundamental, pois (i) assumindo-se ter esse um caráter falacioso, funciona, como como na segunda hipótese apresentada na busca pela verdade, um contra ponto à verdade já estabelecida, fortalecendo sua validade; (ii) fortalece a democracia, visto que possibilita povo a conhecer e entender a idéia contra a qual se luta, na promoção de uma sociedade mais igualitária; (iii) incentiva o desenvolvimento dos indivíduos, os quais, a partir do momento em que são confrontados com tais ideias, serão forçados a refletir sobre elas e a escolher o modelo de sociedade no qual quer viver; e (iv) impõe a todos os indivíduos a capacidade de tolerar as ideias, inclusive as que mais despreze, tornando-os seres mais flexíveis e capazes de conviver com as diferenças.

Entretanto, tal entendimento não é pacífico. Pelo contrário. Provoca enorme discussão doutrinária, despertando teorias diversas sobre o tema. É o caso da feminista norte-americana Catherine A. MacKinnon, cujas ideias tendem a uma solução oposta à acima apresentada. Passa-se, então, à sua análise sobre o tema.

\subsubsection{A crítica ao mercado livre de ideias a partir da teoria de Catherine A. MacKinnon}

A teoria de Catherine A. MacKinnon foi escolhida para ser analisada como contra ponto em razão de suas salutares observações a respeito das deficiências do mercado livre de ideias. Antes, porém, faz-se mister ressaltar que seu enfoque

\footnotetext{
${ }^{60}$ SCHAUER, Frederick. Must speech be special? In. AMAR, Vikram David (Org). The First Amendment Freedom of Speech: its constitutional history and the contemporary debate. New York: Prometheus Books, 2009, p. 96.
} 
teórico é nos problemas atuais enfrentados pelas mulheres na sociedade americana, entendendo-se, para tanto, o conceito de "mulheres" inserido no binário de gênero, ou seja, na ideia dominante de que só há duas opções de identidade de gênero: mulher ou homem; feminino ou masculino; heterossexual ou homossexual.

Assim, a referida autora aborda o problema do discurso de ódio a partir de uma perspectiva feminista ${ }^{62}$, equiparando a pornografia a uma forma de discurso de ódio. Se subordinar é uma prática ativa de colocar alguém em uma posição desigual ou de perda de $\operatorname{poder}^{63}$, a pornografia é uma forma de misoginia, afirma MacKinnon, pois sexualiza a violência. Ou seja, em seu entendimento, a pornografia produz a violência de gênero, em parte, porque reproduz, na tela, os papéis sociais de subordinação $^{64}$. Em suas palavras:

Sim, a pornografia é propaganda; sim, é uma expressão da ideologia do sexo masculino; sim, é literatura de ódio; sim, é a documentação de um crime; sim, é um argumento para o fascismo sexual; sim, é um símbolo, uma representação, um artefato, um sintoma da dominação masculina; sim, transmite ideias como qualquer prática social sistemática faz. (...) Pornografia é um ato sistemático contra as mulheres em todos os níveis de sua existência social. É necessária uma cultura do estupro para requerê-la e permiti-la. São necessários atos contra as mulheres para fazê-la; vendê-la é uma série de atos (transações) os quais fornecem o incentivo para fazê-lo e produzir o abuso em massa; consumi-la é um ato contra as mulheres, o qual gera mais atos que tornam as vidas das mulheres muito mais perigosas, sem sentido, e desiguais. É, portanto, um ato contra as mulheres protegê-la e defendê-la ${ }^{65}$.

Assumindo-se, portanto, que a pornografia é uma das diversas maneiras pelas quais o discurso de ódio se expressa, a teoria de MacKinnon se mostra adequada a

\footnotetext{
${ }^{61}$ VANEIGEM, Raoul. Nada é sagrado, tudo pode ser dito: reflexões sobre a liberdade de expressão. São Paulo: Parábola Editorial, 2004, p. 25.

${ }^{62}$ Há outras teorias feministas que encaram o discurso de ódio de maneira diferente da abordada por Catherine MacKinnon, como é o caso de Ellen Willis e Carole Vance.

${ }^{63}$ DWORKIN, Andrea \& MACKINNON, Catherine A. Pornography and civil rights - a new day for women's equality, 1988. Disponível em http://www.nostatusquo.com/ACLU/dworkin/ other/ordinance/newday/T2c.htm. Acesso em 10.05.2013.

${ }^{64}$ MACKINNON, Catherine A. La pornografía como trata de personas. In: CORLETO, Julieta. Justicia, gênero y violencia. $1^{\text {a }}$ ed. Buenos Aires: Libraria, 2010, p. 101.

${ }^{65}$ DWORKIN, Andrea \& MACKINNON, Catherine A. Pornography and civil rights - a new day for women's equality, 1988. Disponível em http://www.nostatusquo.com/ACLU/dworkin/other/ ordinance/newday/T3.htm. Acesso em 10.05.2013.
} 
ser utilizada para os propósitos do presente trabalho. Porém, uma vez que este estudo não se debruça sobre uma forma de discriminação específica, será feita uma interpretação extensiva de sua teoria, no que couber, para a realização de uma abordagem mais neutra. Desse modo, não será daqui em diante mais falado em "pornografia", mas sim em discurso odioso.

De acordo com a autora, o discurso de ódio transcende a mera expressão de opinião, constituindo uma prática discriminatória de forma verbal ${ }^{66}$. Uma vez que a subjetividade do indivíduo é formada a partir das identidades sociais, a expressão de ódio, alega MacKinnon, possui o cunho de reafirmar sobre o grupo ofendido a subordinação que a sociedade lhe impõe, com a finalidade de destruir a identidade dos sujeitos pertencentes a ele, retirando-lhes a capacidade de se expressar ${ }^{67}$.

Por essa razão, entende que o discurso de ódio é central na criação e na manutenção da desigualdade e, portanto, não deve ser protegido como discurso ${ }^{68}$. Como demonstrado no início do presente trabalho, a participação na vida política requer a liberdade de expressão. A partir do momento em que, alega Catherine MacKinnon, o discurso de ódio silencia a expressão ${ }^{69}$, pode-se concluir que grupos socialmente discriminados não participam da vida política por não serem capazes de se manifestar. Nesse sentido, afirma que o argumento de que o discurso de ódio deve ser entendido como uma forma de manifestação abarcada pela liberdade de expressão acaba por proteger um discurso que não deve ser protegido “e, pior de tudo, invalida os esforços democráticos para promover o princípio da soberania popular" $"$.

\footnotetext{
${ }^{66}$ MACKINNON, Catherine. Only words. Cambridge: Harvard University Press, 1996, p. 99-100.

${ }^{67}$ MACKINNON, Catherine. Are women human? And other international dialogues. Cambridge: Harvard University Press, 2007, p. 227.

${ }^{68}$ DWORKIN, Andrea \& MACKINNON, Catherine A. Pornography and civil rights - a new day for women's equality, 1988. Disponível em http://www.nostatusquo.com/ACLU/dworkin/other/ ordinance/newday/TOC.htm. Acesso em 10.05.2013.

${ }^{69}$ MACKINNON, Catherine A. La pornografía como trata de personas. In: CORLETO, Julieta. Justicia, gênero y violencia. $1^{\text {a }}$ ed. Buenos Aires: Libraria, 2010, p. 102.

${ }^{70}$ SUNSTEIN, Cass R. Free speech now. In. AMAR, Vikram David (Org). The First Amendment Freedom of Speech: its constitutional history and the contemporary debate. New York: Prometheus Books, 2009, p. 101.
} 
Dessa maneira, critica aqueles que defendem um mercado livre de ideias nos moldes acima apresentado. Segundo MacKinnon, proteger manifestações odiosas por serem uma forma de discurso, e, portanto, preservadas, é dizer que, em contra partida, a vida dos membros do grupo ofendido não é importante ${ }^{71}$; que toda uma classe social será subordinada para que outros possam ter o que chamam de liberdade de expressão ${ }^{72}$; que o grupo ofendido deve ser leal à expressão odiosa, pois suas liberdade e igualdade dependem dela ${ }^{73}$. De acordo com a autora, "dizer que quanto mais dano o discurso causar, mais protegido ele será, é legalmente errado" ${ }^{, 4}$. E prossegue:

Às mulheres, as quais viveram em silêncio social, político e legal, é dito que a liberdade de expressão é um direito inviolável e que qualquer tentativa de restringi-lo a qualquer pessoa, restringe-o também às mulheres. Embora as mulheres tenham sido excluídas do acesso aos meios de comunicação, do diálogo político, da educação, da equidade econômica ou do poder político; embora as mulheres sejam forçadas a um silêncio social, pelo desrespeito e pelo terrorismo; embora as mulheres sejam excluídas da participação nas instituições as quais articulam a política social; as mulheres devem prezar pelos direitos de expressão, prezando pelos direitos daqueles os quais as têm excluído ${ }^{75}$.

Assim, demonstra que algumas pessoas possuem muito mais discurso do que outras $^{76}$. Ou seja, a igualdade torna-se um direito do qual aqueles que mais precisam são os menos bem situados para reivindicá-la, fazendo com que as pessoas com um maior grau de igualdade tenham mais condições para reclamar eventuais danos a essas causados ${ }^{77}$.

\footnotetext{
${ }^{71}$ MACKINNON, Catherine. Are women human? And other international dialogues. Cambridge: Harvard University Press, 2007, p. 103.

72 MACKINNON, Catherine. Are women human? And other international dialogues. Cambridge: Harvard University Press, 2007, p. 89 e 90.

${ }^{73}$ DWORKIN, Andrea \& MACKINNON, Catherine A. Pornography and civil rights - a new day for women's equality, 1988. Disponível em http://www.nostatusquo.com/ACLU/dworkin/other/ ordinance/newday/T3.htm. Acesso em 10.05.2013.

${ }_{75}^{74}$ MACKINNON, Catherine. Only words. Cambridge: Harvard University Press, 1996, p. 93.

${ }^{75}$ DWORKIN, Andrea \& MACKINNON, Catherine A. Pornography and civil rights - a new day for women's equality, 1988. Disponível em http://www.nostatusquo.com/ACLU/dworkin/other/ ordinance/newday/T1d.htm. Acesso em 10.05.2013.

${ }^{76}$ MACKINNON, Catherine. Only words. Cambridge: Harvard University Press, 1996, p. 72.

${ }^{77}$ MACKINNON, Catherine. Are women human? And other international dialogues. Cambridge: Harvard University Press, 2007, p. 123.
} 
Dessa maneira, conclui que o discurso de ódio não é fundamental ao mercado livre de ideias, mas sim, o que lhe torna falso. Percebe, então, que a manifestação de cunho odioso (i) não auxilia na busca pela verdade, já que aqueles a quem se dirige o ódio encontram-se em situação de subordinação tal, que não possuem condições de expor suas opiniões e, portanto, não atingindo os requisitos definidos por Stuart Mill; (ii) não fortalece a democracia, pois os indivíduos não são iguais em condições para reivindicar seus direitos; (iii) não incentiva o desenvolvimento da individualidade, pois a finalidade do discurso de ódio é minar com a subjetividade das pessoas pertencentes ao grupo ao qual a ofensa é dirigida; e (iv) não estimula a tolerância por todos, pois só a impõe a quem se encontra subordinado pelo discurso de ódio, visto que este já é, em si, a materialização da intolerância.

Assim como diversos autores apoiam a teoria de Stuart Mill, Catherine MacKinnon também não está sozinha. Daniel Sarmento, por exemplo, apesar de concordar com a importância da busca por um mercado livre de ideias, compreende que o discurso de ódio não se encontra abarcado pela liberdade de expressão. Segundo ele:

[E]ste ambiente [o mercado livre, aberto e robusto] é simplesmente inviabilizado pelo hate speech, que está muito mais próximo de um ataque do que de uma participação num debate de opiniões. Diante de uma manifestação de ódio, há dois comportamentos prováveis da vítima: revidar com a mesma violência, ou retirar-se da discussão, amedrontada e humilhada. Nenhum deles contribui minimamente para "a busca da verdade". Portanto, não é só porque as ideias associadas ao hate speech são moralmente erradas que o Estado deve coibir esta forma discurso. $O$ fato de uma ideia ser considerada errada não é base suficiente para a sua supressão da arena de discussão. Este é o pilar fundamental da liberdade de expressão, que não deve ser ameaçado. Mais relevante do que o erro é a constatação de que as expressões de ódio, intolerância e preconceito manifestadas na esfera pública não só não contribuem para um debate racional, como comprometem a própria continuidade da discussão. Portanto, a busca da verdade e do conhecimento não justifica a proteção ao hate speech, mas, pelo contrário, recomenda a sua proibição ${ }^{78}$.

\footnotetext{
${ }^{78}$ SARMENTO, Daniel. A liberdade de expressão e o problema do hate speech. Revista de Direito do Estado. Rio de Janeiro: Renovar, 2006, p. 53-106.
} 
Assim, entende MacKinnon que o Estado tem o dever de atuar de maneira a impedir tais manifestações. Segundo ela, a omissão do Estado diante de uma manifestação pública de ódio ou de um ato de desrespeito a minorias transmite a todos, ofensor e ofendido, o sinal de que não vê nada de errado em tal conduta. Em consequência, como afirma Daniel Sarmento, "[a] dor e a sensação de abandono dos alvos destas manifestações tendem a ser amplificadas, e o símbolo que fica - e todos sabemos da importância dos símbolos na vida social - é o de um Estado cúmplice da barbárie" 79 .

Como resposta ao problema, MacKinnon desenvolve, em conjunto com outra feminista americana, Andrea Dworkin, uma solução na qual afirmam uma participação positiva do Estado. De acordo com elas, e ao contrário do que afirmam os defensores da primeira teoria apresentada, a edição de uma lei apresenta-se como a arma principal na luta pela igualdade das minorias sociais. Em suas palavras: “[s]omos instruídos a usar a educação, não a lei, na mudança de atitudes. Tradução: os homens continuam a divertir-se em abusar de mulheres impunimente, enquanto nós tentamos fazê-los ter pensamentos melhores" ${ }^{\prime 80}$.

E mais: tendo-se em vista que é o opressor o detentor do poder, é ele quem ocupa os cargos socialmente influentes. Portanto, os textos legais tendem a reproduzir o seu ponto de vista das questões que afetam de forma particular o oprimido. É por essa razão que, embora acreditem que um instrumento legal seja a via ideal para se alcançar reais transformações sociais, defendem também que a mera edição de lei não é suficiente, devendo essa ser pensada pelos indivíduos pertencentes aos grupos vulneráveis, refletindo as suas percepções acerca das questões que os produzem. Exemplifica Catherine MacKinnon:

Mas o fato de que a lei de estupro protege estupradores e é escrito a partir de seu ponto de vista a garantir a impunidade para a maioria dos estupros é

\footnotetext{
${ }^{79}$ SARMENTO, Daniel. A liberdade de expressão e o problema do hate speech. Revista de Direito do Estado. Rio de Janeiro: Renovar, 2006, p. 53-106.

${ }^{80}$ MACKINNON, Catherine. Are women human? And other international dialogues. Cambridge: Harvard University Press, 2007, p. 103.
} 
oficialmente considerada como uma violação da lei de igualdade entre os sexos, nacional ou internacional, por praticamente ninguém ${ }^{81}$.

Como resultado das análises acima apresentadas, as próprias autoras esboçaram um modelo de lei. Uma vez que, como anteriormente afirmado, o foco de análise de MacKinnon, e também o de Dworkin, é a subordinação das mulheres, a Lei, como a chamam $^{82}$, tem por tema central o controle da pornografia como discurso de ódio. Afirmam ambas as teóricas:

As mulheres precisam de leis que tratem das formas como as mulheres são mantidas em segunda classe: as sanções institucionais de violência e de violação, de jure e de fato; os padrões de exploração e de aviltamento; as sistemáticas lesões contra a integridade, a liberdade, a igualdade e a autoestima $^{83}$.

De tal maneira, pensaram em uma lei cujo objetivo fosse empoderar as mulheres diante do discurso de ódio, em especial, as diretamente vitimizadas nas produções pornográficas. Em conformidade com o defendido por elas, a Lei torna possível às vítimas processar aqueles que as subordinam, mediante comprovação do prejuízo que tenham sofrido. A Lei, alegam, baseia-se na prova de dano, e não no julgamento de ideias ${ }^{84}$ e tem como propósito a indenização civil dos danos, a fim de compensar a vítima pela lesão, e não a condenação penal ${ }^{85}$.

Dessa maneira, pode-se perceber que Catherine MacKinnon opõe-se à ideologia de Stuart Mill. Não por considerar a liberdade de expressão um direito menos importante, mas sim, por entender que o discurso de ódio não se insere no conceito de liberdade de expressão, sendo, porém, um limite a essa.

\footnotetext{
${ }^{81}$ MACKINNON, Catherine. Are women human? And other international dialogues. Cambridge: Harvard University Press, 2007, p. 25.

82 "The Ordinance", em inglês. In: DWORKIN, Andrea \& MACKINNON, Catherine A. Pornography and civil rights - a new day for women's equality, 1988. Disponível em http://www.nostatusquo.com/ACLU/dworkin/other/ ordinance/newday/T1a.htm. Acesso em 10.05.2013.

${ }^{83}$ DWORKIN, Andrea \& MACKINNON, Catherine A. Pornography and civil rights - a new day for women's equality, 1988. Disponível em http://www.nostatusquo.com/ACLU/dworkin/other/ ordinance/newday/T1a.htm. Acesso em 10.05.2013.

${ }^{84}$ DWORKIN, Andrea \& MACKINNON, Catherine A. Pornography and civil rights - a new day for women's equality, 1988. Disponível em http://www.nostatusquo.com/ACLU/dworkin/other/ ordinance/newday/T1a.htm. Acesso em 10.05.2013.
} 
Visto o debate no campo das ideias, passa-se agora à análise de decisões jurisprudenciais. A fim de ater-se aos limites do presente e trabalho e levando-se em conta a impossibilidade de se analisar toda a jurisprudência acerca do tema, será apresentado, de maneira exemplificativa, o entendimento dos órgãos dos sistemas interamericano e europeu de proteção aos direitos humanos e, no âmbito do direito comparado, os Estados Unidos da América e o Brasil. É o que se passa a analisar no próximo capítulo.

${ }^{85}$ DWORKIN, Andrea \& MACKINNON, Catherine A. Pornography and civil rights - a new day for women's equality, 1988. Disponível em http://www.nostatusquo.com/ACLU/dworkin/other/ ordinance/newday/T1a.htm. Acesso em 10.05.2013. 


\section{CAPÍTULO 2. A SOLUÇÃO JURISPRUdENCIAL DAS CORTES INTERNACIONAIS E DO DIREITO COMPARADO}

O que é liberdade de expressão? Sem a liberdade de ofender, ela deixa de existir.

- Salman Rushdie

A discussão acima apresentada não está restrita ao campo teórico. A jurisprudência, nas diversas partes do mundo, encontra soluções diferentes e até antagônicas, como afirmou Winfried Brugger: "[d]e modo geral, nem o direito constitucional moderno nem o direito internacional permitem ou pró́bem o discurso do ódio de maneira consistente" ${ }^{\sharp 6}$. A fim de ilustrar essa questão, serão analisadas decisões paradigmáticas do direito internacional e do direito comparado, tendo-se como base os quatro sistemas jurídicos objetos de estudo do presente trabalho, quais sejam: os sistemas interamericano e europeu de direitos humanos, o norte-americano e o brasileiro.

\subsection{O Sistema interamericano de proteção aos direitos humanos}

No sistema interamericano, não há manifestação jurisprudencial sobre a tensão entre liberdade de expressão e discursos de ódio. Todavia, tanto a Corte Interamericana de Direitos Humanos, quanto a Comissão Interamericana de Direitos Humanos, já deixaram sua posição expressa em opiniões consultivas, em informes e em relatórios sobre o tema.

De acordo com os órgãos supra citados, há uma presunção de proteção de todos os discursos. Assim, entende-se que, a princípio, os Estados não podem restringir o direito à liberdade de expressão, o qual abraça as mais diversas formas que o discurso pode assumir, independentemente de seu conteúdo, protegendo-as. Isso significa dizer, como já enfatizou a Relatoria

\footnotetext{
${ }^{86}$ BRUGGER, Winfried. Proibição ou proteção do discurso do ódio - Algumas observações sobre o direito alemão e o americano. Direito Público. Porto Alegre, n. 15, p. 118, jan./mar. 2007.
} 
para a Liberdade de Expressão ${ }^{87}$, que, a priori, não existem pessoas, grupos, ideias ou meios de expressão excluídos do debate público ${ }^{88}$. Nesse sentido, a Corte explica que a liberdade de expressão deve ser garantida:

"não só quanto à difusão de ideias e de informações recebidas favoravelmente, ou consideradas inofensivas ou indiferentes, como também, quanto às que ofendem e chocam. Assim o exigem o pluralismo, a tolerância e o espírito de abertura, sem os quais não existe uma sociedade democrática" ${ }^{, 89}$.

Entretanto, a própria Convenção Americana sobre Direitos Humanos

reconhece não ser a liberdade de pensamento e de expressão um direito absoluto. Dessa forma, permite a imposição de certas restrições, as quais devem obedecer aos requisitos do artigo 13(2) deste instrumento legal. Assim sendo, a Corte e a Comissão têm se posicionado de maneira a afirmar que o direito à liberdade de expressão não é absoluto e, portanto, pode estar sujeito a certas limitações. Baseando-se no artigo 13(2)(4) e (5) da Convenção, afirmam, respectivamente, que:

"O artigo 13(2) da Convenção define os meios pelos quais podem ser estabelecidos limites admissíveis à liberdade de expressão. Estipula, em primeiro lugar, que a censura prévia é sempre incompatível com o pleno exercício dos direitos previstos no artigo 13, mas para a exceção prevista no parágrafo 4 lidam com espetáculos públicos, mesmo que o alegado propósito de tal censura prévia é para evitar abusos de liberdade de expressão. Nesta área, qualquer medida preventiva, inevitavelmente, equivale a uma violação da liberdade garantido pela Convenção" $"$.

[P]ara serem legítimas, [as limitações] devem cumprir uma série de condiciones específicas. Particularmente, o artigo 13.2 exige $\mathrm{o}$ cumprimento de três condições básicas para que una limitação ao direito

\footnotetext{
87 “A Relatoria Especial foi criada para promover a consciência para o pleno respeito do direito à liberdade de expressão e informação no hemisfério, considerando o papel fundamental que este direito tem no fortalecimento e desenvolvimento do sistema democrático e da comunicação e protecção de outros direitos humanos". Disponível em http://www.oas.org/es/cidh/expresion/ index.asp. Acesso em 26.04.2013.

${ }^{88}$ CIDH. Informe Anual 2012. Informe de la Relatóría para la Libertad de Expresión. Capítulo III (Jurisprudência nacional en materia de libertad de expresión). OEA/Ser.L/V/II.147. Doc. 1.5 de março de 2013, par. 36.

${ }^{89}$ Corte IDH. Caso Herrera Ulloa v. Costa Rica. São José, Costa Rica. Sentença em 2 de julho de 2004, par. 113.

${ }^{90}$ Corte IDH. La colegación obligatória de periodistas. Opinião Consultiva OC-5/85, de 13 de novembro de 1985, par. 54.
} 
à liberdade de expressão seja admissível: 1) a limitação deve ter sido definida em forma precisa e clara através de uma lei formal e material, 2) a limitação deve estar orientada ao logro de objetivos legítimos autorizados pela Convenção Americana, e 3) a limitação deve ser necessária em una sociedade democrática para o logro dos fins legítimos que se buscam; estritamente proporcional à finalidade perseguida; e idôneos para lograr o objetivo imperioso que pretende lograr ${ }^{91}$.

Assim sendo, percebe-se que o sistema interamericano concebe a possibilidade de restrições à liberdade de expressão ${ }^{92}$. Desde que, porém, não sejam realizadas através de medidas prévias, mas somente, através da imposição posterior de sanções àqueles cujas atitudes tenham sido consideradas abusivas e extravagantes à liberdade de expressão, respeitados os requisitos impostos pela Convenção Americana. Portanto, como já estabelecido pela Corte, isso significa que só será possível determinar as situações em que houve, ou não, transgressão ao direito de livremente se manifestar e se houve, ou não, excessiva atuação repressiva, em cada caso concreto $^{93}$.

No entanto, em conformidade com o artigo 1(1) da Convenção Americana ${ }^{94}$, outro pilar dos sistemas democráticos, além da liberdade de

${ }^{91}$ CIDH, Informe Anual de la Relatóría para la Libertad de Expresión. In: Informe Anual 2012. Washington DC, 5 de março de 2013, par. 68.

${ }^{92}$ Há uma divergência, porém, no tocante às leis de desacato. A Comissão entende que as leis de desacato são incompatíveis com a Convenção Americana sobre Direitos Humanos, pois outorgam injustificadamente um direito à proteção do qual não dispõem os demais integrantes da sociedade, invertendo o princípio fundamental de um sistema democrático em que o governo é objeto de controle pelos cidadãos, a fim de que possam controlar os abusos de poder (CIDH, Informe sobre la Compatibilidad entre las Leyes de Desacato y la Convención Americana sobre Derechos Humanos. In: OAS Doc. 9, 88 Período de Sessões, 17 de fevereiro de 1995). Já a Corte estabeleceu no caso Kimel v. Argentina que as leis de desacato, per se, não caracterizam uma afronta à liberdade de expressão, devendo, contudo, estar em concordância com os objetivos estabelecidos no artigo 13(2) da Convenção Americana (Corte IDH. Caso Kimel v. Argentina. São José, Costa Rica. Sentença em 2 de maio de 2008).

${ }_{93}$ Corte IDH. La colegación obligatória de periodistas. Opinião Consultiva OC-5/85, de 13 de novembro de 1985

${ }_{94}$ Artigo 1. Obrigação de respeitar os direitos. (1) Os Estados Partes nesta Convenção comprometem-se a respeitar os direitos e liberdades nela reconhecidos e a garantir seu livre e pleno exercício a toda pessoa que esteja sujeita à sua jurisdição, sem discriminação alguma por motivo de raça, cor, sexo, idioma, religião, opiniões políticas ou de qualquer outra natureza, origem nacional ou social, posição econômica, nascimento ou qualquer outra condição social. (2) Para os efeitos desta Convenção, pessoa é todo ser humano. Em: OEA. Convenção Americana sobre Direitos Humanos. Conferência Especializada Interamericana sobre Direitos Humanos, San José, Costa Rica, 22 de novembro 1969. 
expressão, é o respeito aos direitos fundamentais de igualdade e de não discriminação. A Corte já se posicionou nesse sentido e entendeu que "o princípio de igualdade perante a lei, igual proteção perante a lei e não discriminação, ingressaram, na atual etapa da evolução do direito internacional, no domínio do jus cogens" e, consequentemente, "os Estados não podem discriminar ou tolerar situações discriminatórias" ${ }^{95}$. Nesse sentido, a Comissão já afirmou que:

"A história hemisférica tem demonstrado que um dos desafios principais para a consolidação de democracias requer que se intensifique a participação de todos os setores sociais na vida política, social, econômica e cultural de cada nação (...). A falta de participação equitativa impede o desenvolvimento de sociedades democráticas e pluralistas, exacerbando a intolerância e a discriminação. A inclusão de todos os setores da sociedade nos processos de comunicação, decisão e desenvolvimento é fundamental para que suas necessidades, opiniões e interesses sejam contemplados no projeto de políticas e na toma de decisões" 96 .

Como resultado, a Corte e a Comissão impõem aos Estados o dever de eliminar qualquer forma de discriminação as quais possam levar indivíduos a serem excluídos de uma plena participação na sociedade. Assim, devem procurar a eliminação de todo tipo de medidas que discriminem o individuo, impossibilitando-o de uma participação plena na vida política, econômica, pública e social de seu país Assim determinaram, respectivamente, a Comissão e a Corte:

"[É] dever do Estado garantir a igualdade de oportunidades a todas as pessoas para que possam receber, buscar e transmitir informação por qualquer meio de comunicação sem discriminação, eliminando todo tipo de medidas que discriminem a um individuo ou grupo de pessoas em sua participação igualitária e plena da vida política, econômica e social

\footnotetext{
${ }^{95}$ Corte IDH. Caso Vélez Loor v. Panamá. São José, Costa Rica. Sentença em 23 de novembro de 2010, par. 248.

${ }^{96}$ CIDH. Informe Anual de la Relatoría para la Libertad de Expresión, 2002. OEA/Ser.L/V/II.147 Doc.1. 5 de março de 2013. Cap. IV, par. 10-14.
} 
de seu país. Esse direito garante uma voz informada a todas as personas, condição indispensável para a subsistência da democracia" ${ }^{" 97}$.

Por conseguinte, os Estados têm a obrigação de não introduzir em seu ordenamento jurídico regulações discriminatórias, eliminar as regulações de carácter discriminatório, combater as práticas deste carácter e estabelecer normas e outras medidas que reconheçam e assegurem a efetiva igualdade perante a lei de todas as personas" ${ }^{\prime 98}$.

Quanto ao discurso de ódio, especificamente, não há manifestação expressa de nenhum dos órgãos do sistema interamericano. Contudo, no caso Kimel v. Argentina, a Corte, ao mencionar a ponderação de princípios quando houver grave conduta do emissor da ideia, relacionou, em nota de roda pé, tais situações a casos da Corte Européia de Direitos Humanos, nos quais esta se manifestou contrária à inclusão de tais expressões no rol de manifestações a serem protegidas pelo artigo 10 da Convenção Européia ${ }^{99}$. De tal modo, somando-se isso ao que foi dito anteriormente, pode-se concluir que o sistema interamericano de proteção aos direitos humanos não entende ser o discurso de ódio abarcado pela liberdade de expressão.

\subsection{A Corte Européia de Direitos Humanos}

$\mathrm{Na}$ Corte Européia de Direitos Humanos, por outro lado, já existe manifestação jurisprudencial acerca do tema. Antes de abordar o discurso de ódio no sistema europeu de proteção aos direitos humanos, porém, faz-se mister ressaltar que essa reconhece o caráter fundamental da liberdade de expressão na sustentação e uma sociedade democrática. Assim explicou no caso Handyside v. United Kingdom:

"A liberdade de expressão constitui um dos fundamentos essenciais de uma sociedade, é uma das condições básicas para o seu progresso e para o desenvolvimento de cada homem. Sujeito ao parágrafo 2 do artigo 10

\footnotetext{
${ }^{97}$ CIDH. Informe Anual de la Relatoría para la Libertad de Expresión, 2002. OEA/Ser.L/V/II.147 Doc.1. 5 de março de 2013. Cap. IV, par. 7.

${ }^{98}$ Corte IDH. Caso Vélez Loor v. Panamá. São José, Costa Rica. Sentença em 23 de novembro de 2010, par. 248.

${ }^{99}$ Corte IDH. Caso Kimel v. Argentina. Sentença em 2 de maio de 2008, par. 78 (nota 57).
} 
o, é aplicável não apenas à "informação" ou "ideias" recebidas as quais sejam favoráveis, ou consideradas inofensivas ou indiferentes, mas também àquelas que ofendem, que chocam ou que inquietam o Estado ou qualquer setor da população. Essas são as exigências do pluralismo, da tolerância e do espírito de abertura, sem os quais não há uma sociedade democrática" $"$.

Porém, afirma que tal direito não é de caráter absoluto. Assim, determina que alguns limites devem ser estabelecidos e, desse modo, estipula, a título ilustrativo, que o direito à reputação, ao bom nome e à reputação constituem um de tais limites, como definiu no caso Middelburg, Van Der Zee And Het Parool B.B. v. The Netherlands:

"[L]evando em conta os deveres e as responsabilidades inerentes ao direito à liberdade de expressão garantida pelo artigo 10 da Convenção e a obrigação de fornecer uma medida de proteção ao direito de privacidade de um indivíduo afetado por outros, (...) a Corte não pode achar que seja razoável que, depois de ter examinado e equilibrado os interesses em questão, os tribunais internos tenham rejeitado o argumento dos requerentes de que o direito à liberdade de expressão deve prevalecer sobre o direito à proteção ao bom nome e à reputação e chegou à conclusão oposta" ${ }^{, 101}$.

Em consequência, determina a Corte Européia que a extrapolação ao limite da liberdade de expressão está sujeita a sanções. Afirma, porém, que, o conflito deve ser solucionado a partir de uma ponderação de princípios segundo a qual, portanto, as sanções impostas a tais manifestações indevidas devam ser proporcionais ao objetivo legítimo perseguido. Assim decidiu no caso Otto-Preminger-Institut v. Austria:

[C]omo é confirmado pela própria redação do artigo 10, parágrafo 2 (art. 10-2), quem exerce os direitos e liberdades consagrados no primeiro parágrafo do mesmo artigo (art. 10-1) compromete-se a "deveres e responsabilidades". Entre eles - no contexto de opiniões e crenças religiosas - pode legitimamente ser incluída a obrigação de

\footnotetext{
${ }^{100}$ Corte Européia. Caso Handyside v. United Kingdom. Sentença em 7 de dezembro de 1976, Series A No. 24, par. 49.

${ }^{101}$ Corte Européia. Caso Middelburg, Van Der Zee And Het Parool B.V. v. The Netherlands. Sentença em 21 out. 1998.
} 
evita, na medida do possível, expressões as quais sejam uma ofensa gratuita a outros e, portanto, uma violação dos seus direitos, e não contribuam para qualquer tipo de debate público capaz de promover o progresso nas relações humanas. (...) A Corte não pode ignorar o fato de que a religião católica é a religião da maioria esmagadora dos tiroleses. Na apreensão do filme, as autoridades austríacas agiram a fim de garantir a paz religiosa na região e a evitar que algumas pessoas sentissem-se objeto de ataques a suas crenças religiosas de forma injustificada e ofensiva. Em primeiro lugar, as autoridades nacionais estão em uma melhor posição em relação ao juiz internacional para avaliar a necessidade de tal medida à luz da situação existente no local, em um determinado momento. Em todas as circunstâncias do presente caso, a Corte não considera que as autoridades austríacas possam ser condenadas por terem ultrapassado a sua margem de apreciação a este respeito ${ }^{102 .}$

Além do direito acima afirmado, a Corte Europeia entende que o discurso de ódio é outro limite a ser imposto à liberdade de expressão. A fim de exemplificar seu posicionamento acerca do tema, será analisado o caso Lindon,Otchakovsky-Laurens and July v. France, julgado pela mesma em 22 de outubro de 2007. O caso em tela se trata da condenação pelo Estado francês de três cidadãos seus, os quais dão nome ao caso. O sr. Lindon é um escritor, o sr. Otchakovsky-Laurens, é presidente do conselho de administração da empresa de publicação a qual publicou o livro do primeiro requerente, e o sr. July foi o diretor da publicação do jornal diário "Libération".

O sr. Lindon é o autor do livro intitulado "Le Procès de Jean-Marie Le Pen", o qual narra o julgamento de um militante da Frente Nacional, Ronald Blistier. O personagem em questão colava cartazes pela cidade, quando comete o assassinato, a sangue frio, de um jovem norte-africano por motivação racista. O romance, porém, foi baseado nos homicídios, em 1995, de Brahim Bouaram, um jovem marroquino atirado ao Sena por "skinheads" durante uma marcha da Frente Nacional, e de Ibrahim Ali, um jovem francês de origem das Comores, morto em Marselha por militantes do mesmo partido. Como afirmado pela

\footnotetext{
${ }^{102}$ Corte Européia. Caso Otto-Preminger-Institut v. Austria. Sentença em 20 set. 1994, Series A No. 295-A, par. 49 e 56.
} 
Corte, "[o] romance centra-se em uma série de figuras que são caracterizados por suas posições morais ou políticos em relação à ideologia e partido político de extrema direita", procurando destacar as dificuldades e as contradições de certas posturas "anti-racistas"103.

Em razão disso, os srs. Lindon e Otchakovsky-Laurens foram criminalmente condenados. Em 11 de Outubro de 1999, o Tribunal Criminal de Paris condenou-os, respectivamente, por difamação e por cumplicidade na difamação ${ }^{104}$. Em reação a tal condenação, em 16 de novembro de 1999, em uma coluna intitulada "Rebonds", do jornal "Libération", publicou um artigo sobre a condenação, assinado por noventa e sete escritores contemporâneos, o qual tomou a forma de uma petição, com a seguinte redação: "Petição. As passagens do livro 'Jean-Marie Le Pen on Trial' pelo que Mathieu Lindon e seu editor foram condenados não são difamatórias. Estamos preparados para escrevê-los em um romance. Vamos escrever contra Le Pen". Por conta de tal artigo, o sr. July foi condenado, em 7 de setembro de 2000, pelo Tribunal Criminal Criminal de Paris, por incorrer no crime de difamação ${ }^{105}$, pois considerou o Tribunal que:

“[E]mbora o jornal Libération tenha o direito de comentar sobre a decisão judicial e transmitir idéias e informações sobre questões que formam o tema do debate público, (...) a publicação das passagens difamatórias em abstracto, fora do seu contexto literário, reforçou a força desonrosa das alegações, as quais foram transferidas para o terreno da realidade e da plausibilidade, sem qualquer debate de idéias"106.

Nesse caso, a Corte Europeia entendeu se tratar de manifestação odiosa. Em relação aos dois primeiros autores, decidiu que o Estado francês não violou o artigo 10 da Convenção Europeia ao condená-los, visto que "os discursos e

\footnotetext{
${ }^{103}$ Corte Européia. Caso Lindon, Otchakovsky-Laurens and July v. France. Sentença em 22 de outubro de 2007, cap. I, par. 11.

${ }^{104}$ Corte Européia. Caso Lindon, Otchakovsky-Laurens and July v. France. Sentença em 22 de outubro de 2007, cap. I, par. 14.

${ }^{105}$ Corte Européia. Caso Lindon, Otchakovsky-Laurens and July v. France, Sent. 22 out. 2007, cap. I, par. 21-22.

${ }^{106}$ Corte Européia. Caso Lindon, Otchakovsky-Laurens and July v. France, Sent. 22 out. 2007, cap. I, par. 23.
} 
as opiniões do Sr. Jean-Marie Le Pen incitam e provocam o ódio e a violência, para o qual ele foi condenado" ${ }^{107}$. Em seguida, afirmou que:

"[a] Corte reitera que leva em conta a natureza das observações feitas, em especial para a intenção subjacente a estigmatizar o outro lado, e ao fato de que seu conteúdo é de molde a suscitar a violência e o ódio, indo assim além do que é tolerável no debate político, mesmo em relação a uma figura que ocupa uma posição extremista no espectro político"108.

Quanto ao terceiro candidato, o diretor de publicação do Libération, na verdade não era, talvez, aconselhável permitir noventa e sete escritores de usar uma coluna de jornal para expressar tais opiniões. No entanto, como o Tribunal de Justiça encontrado no presente acórdão, uma vez que a liberdade de imprensa está em causa "este é um caso que atrai um nível particularmente elevado de proteção da liberdade de expressão nos termos do artigo 10". Não se contesta que o artigo foi publicado no contexto de informações e ideias sobre questões de interesse público ${ }^{109}$.

Assim, tendo-se em vista a posição da Corte Européia no caso acima mencionado, pode-se perceber que a mesma não inclui o discurso de ódio no rol das manifestações a serem protegidas. Uma vez que não considera a proibição por um Estado de determinado tipo de discurso uma violação ao artigo 10 da Convenção Européia, a Corte posiciona-se de maneira a afirmar que as manifestações odiosas não se encontram protegidas pelo sistema europeu de proteção aos direitos humanos, sob o artigo referido.

Demonstradas as posições dos sistemas interamericano e europeu de proteção aos direitos humanos, pode-se perceber que o direito internacional não incluiu o discurso de ódio na proteção da liberdade de expressão. Assim, passamos ao direito comparado, com a análise de decisões da Suprema Corte norte-americana e do Supremo Tribunal Federal brasileiro.

\footnotetext{
${ }^{107}$ Corte Européia. Caso Lindon, Otchakovsky-Laurens and July v. France, Sent. 22 out. 2007, cap, II par. 5.

${ }^{108}$ Corte Européia. Lindon, Otchakovsky-Laurens and July v. France, Sent. 22 out. 2007, cap, II par. 6
} 


\subsection{Os Estados Unidos da América}

No direito americano, o tema é juridicamente pacífico, apesar de não o ser socialmente, com jurisprudência já consolidada pela Suprema Corte dos Estados Unidos sobre o tema. Assim como nos sistemas internacionais, nos Estados Unidos, a liberdade de expressão não é absoluta, podendo ser restringida em razão do lugar, do tempo e da forma, ou se a informação veiculada contiver o que se convencionou chamar de "real malícia".

A primeira vez que a Suprema Corte enfrentou a questão do discurso de ódio foi no caso Beauharnais vs. Illinois, em 1952. Discutia-se, no julgamento, a condenação criminal de um indivíduo que promovera a distribuição de panfletos em Chicago, nos quais conclamava os brancos a se unirem contra os negros e evitarem a miscigenação racial, acusando os afrodescendentes de serem os responsáveis por estupros, roubos e outros crimes. A condenação baseara-se em lei estadual que proibira a exibição em qualquer espaço público de publicações que imputassem a grupos identificados pela raça, cor, credo ou religião, de características negativas ligadas à "devassidão, criminalidade, falta de castidade ou de virtude", e que com isso expusessem os integrantes destes grupos ao desprezo ou pudessem implicar em desordem e tumultos. A Suprema Corte manteve a condenação, considerando constitucional a lei aplicada, que havia sido questionada em razão de alegada ofensa à liberdade de expressão, e validou com isso a ideia de difamação coletiva ${ }^{110}$.

Porém, esta posição não tardou a ser revertida. Com efeito, no julgamento do caso Brandemburg vs. Ohio, em 1969, a Suprema Corte norteamericana reformou decisão que condenara Brandemburg, um líder da KuKluxKlan no Estado de Ohio, pelo delito de apologia ao crime. Este

\footnotetext{
${ }^{109}$ Corte Européia. Lindon, Otchakovsky-Laurens and July v. France, Sent. 22 out. 2007, cap. III, par. 1
} 
indivíduo organizara e promovera um encontro daquela nefasta entidade, para o qual convidara um repórter, que transmitiu ao público, pela televisão, algumas imagens do evento. Na filmagem, viam-se pessoas encapuzadas queimando cruzes e proferindo palavras de ordem contra negros e judeus. Em um dado momento, Brandemburg usou da palavra para dizer que "os crioulos (nigger) deveriam ser devolvidos para a África e os judeus para Israel”, e, em outra passagem, proferiu ameaça, afirmando que se o Presidente, o Congresso e a Suprema Corte continuassem a prejudicar a raça caucasiana, a KuKluxKlan poderia tentar se vingar.

A decisão da Suprema Corte, considerou inconstitucional a lei do Estado de Ohio. De acordo com ela, a referida lei punia a defesa de uma ideia, o que seria plenamente incompatível com a liberdade de expressão. Nas palavras da Corte,

"as garantias constitucionais da liberdade de expressão e liberdade de imprensa não permitem que o Estado proíba a defesa do uso da força ou da violação da lei, exceto quando esta defesa seja direcionada a incitar ou promover ação ilegal, e seja adequada ao incitamento ou à produção desta ação" $" 111$.

Essa não foi a única oportunidade em que a Suprema Corte pode se manifestar. Em 1976, o Partido Nacional-Socialista planejou uma passeata, em diversos locais, dentre os quais o distrito de Skokie, em Illinois, área cuja ocupação é predominantemente judaica. Porém, foi-lhe negada a permissão, com fulcro em legislações locais as quais inviabilizaram a ocorrência da manifestação por exigirem um mínimo de US\$ 350.000 para passeatas com mais de cinquenta pessoas (Lei ${ }^{\circ}$ 994), por proibirem a divulgação de material o qual incitasse ao ódio racial ou religioso (Lei $\mathrm{n}^{\circ}$ 995), e por proibirem

\footnotetext{
${ }^{110}$ Supreme Court of the United States. Beauharnais v. Illinois, 343 U.S. 250 (1952). Sentença em 28 de abril de 1952.

${ }^{111}$ Supreme Court of the United States. Brandenburg v. Ohio, 395 U.S. 444 (1969). Sentença em 9 de junho de 1969.
} 
manifestações públicas por membros de partidos políticos vestidos em uniformes de estilo militar (Lei $\mathrm{n}^{\text {o }}$ 996) ${ }^{112}$.

Os membros do Partido Nacional-Socialista, então entraram em juízo com o intuito de ver tais ordenações declaradas inconstitucionais. Sob as alegações de que uniformes com suásticas e cartazes com os dizeres "liberdade de expressão para o homem branco" e "liberdade de expressão para os americanos brancos" seriam discursos a serem protegidos, entraram com uma ação contra Skokie para que as leis as quais os estavam impedindo de realizar a passeata fossem consideradas inconstitucionais e, então, pudessem realizá-la. Em primeiro grau, o juiz Decker considerou que:

“(1) a lei exigindo que grupos de 50 ou mais pessoas obtivessem seguro de responsabilidade civil, no valor de pelo menos US\$ 300mil, e propriedade seguro de danos, no valor de pelo menos US\$ 50mil dólares, era inconstitucional; (2) a lei proibindo a disseminação de materiais que tendessem a promover ou a incitar o ódio racial ou religioso era inconstitucionalmente vaga e demasiado ampla; (3) a lei impedindo a emissão de licença para qualquer pessoa a fim de que impedir a realização de uma passeata licença para que não fosse divulgado determinado material impõe uma censura prévia inconstitucional; e (4) a lei proibindo os membros de um partido político de realizarem uma passeata vestidos com uniformes de estilo militar era inconstitucional"113.

A cidade de Skokie recorreu e a Corte do Distrito de Illinois manteve a decisão. Seguindo o entendimento previamente estabelecido pela Suprema Corte norte-americana, a Corte de Illinois reiterou que a partir do momento em que o discurso envolvido toma a forma da defesa de ideias, o único motivo que sustenta a sua restrição é a existência de ameaça de iminente ação ilegal. Nesse sentido, afirmou que:

"No entanto, a incitação ao ódio muitas vezes é um subproduto do debate vigoroso sobre assuntos altamente emocionais, e a mensagem básica de Cohen é que uma

\footnotetext{
${ }^{112}$ United States District Court, N.D. Illinois. Smith v. Collin [447 F.Supp. 676]. Sentença em 23 de fevereiro de 1978.

${ }^{113}$ United States District Court, N.D. Illinois. Smith v. Collin [447 F.Supp. 676]. Sentença em 23 de fevereiro de 1978.
} 
grande quantidade de linguagem inútil, ofensiva e até mesmo potencialmente prejudicial deve ser tolerada, como parte da "cacofonia verbal" que acompanha o debate desinibido; não para o seu próprio bem, mas porque qualquer tentativa de extirpar-lo do debate público com o instrumento contundente de sanções penais deve inevitavelmente ter um efeito negativo sobre o vigor desse discurso. (...) e a Corte deixou claro que o discurso não pode ser punido apenas porque ofende. Liberdade de pensamento traz consigo a liberdade para falar livremente e reunir publicamente para expressar os pensamentos. A capacidade da sociedade americana de tolerar a defesa, mesmo das doutrinas de ódio defendidas pelos autores, sem abandonar o seu compromisso com a liberdade de expressão e reunião, é, talvez, a melhor proteção que temos contra o estabelecimento de qualquer tipo de regime nazista no país"114.

O caso, porém, não se encerrou no estado de Illinois, chegando, primeiramente, à Corte de Apelação dos Estados Unidos e, posteriormente, à Suprema Corte. Em ambas as instâncias, o entendimento que vingou foi o de que o discurso de ódio estaria protegido pela Primeira Emenda à Constituição.

De acordo com a Corte de Apelação "[a] tirania ideológica, não importa quão digna a sua motivação, é proibida tanto para juízes nomeados, quanto para legisladores eleitos" ${ }^{115}$. Explicou que:

"Seria extremamente insensível negar, como não o fazemos, que a menifestação proposta perturba séria, mental e emocionalmente, pelo menos, alguns e, provavelmente, muitos dos moradores da vila. O problema em enxertar uma exceção na Primeira Emenda para tais situações é que elas [as expressões de ódio] são indistinguíveis, em princípio, a partir de discurso que "convidam a discutir.... Induzem a uma condição de instabilidade, criam insatisfação com as condições, ou mesmo provocam raiva nas pessoas". No entanto, essas estão entre os "elevados propósitos" da Primeira Emenda. É perfeitamente claro que um Estado de muitos não [deva] fazer criminosa a expressão pacífica de opiniões impopulares. Da mesma forma, a mera intolerância pública ou animosidade não podem ser a base para a simplificação dessas liberdades constitucionais. (...) Embora teria pensado desnecessário dizê-lo, aparentemente merece ênfase à luz da referência da dissidência a este tribunal pedindo desculpas quanto ao resultado, que o nosso pesar pelos apelados cujo uso dos seus direitos não é em nenhum sentido uma apologia à defesa da Primeira Emenda. O resultado que atingimos é ditado pela proposição fundamental de que, se esses direitos civis devem permanecer vital para todos, eles

\footnotetext{
${ }^{114}$ United States District Court, N.D. Illinois. Smith v. Collin [447 F.Supp. 676]. Sentença em 23 de fevereiro de 1978.

${ }^{115}$ United States Court of Appeals, Seventh Circuit. Smith v. Collin [578 F.2d 1197]. Sentença em 22 de maio de 1978.
} 
devem proteger não só aqueles os quais a sociedade considera aceitável, mas também aqueles cujas ideias bastante justificadamente rejeita e despreza" ${ }^{, 16}$.

Na mesma linha, a Suprema Corte dos Estados Unidos, que decidiu o caso em 16 de outubro de 1978, declarou inconstitucional a aplicação das citadas leis de Skokie ${ }^{117}$. Em sua decisão, estipulou que o discurso de ódio é uma forma de discurso político e que, portanto, qualquer restrição ao primeiro configura também uma restrição ao segundo. Dessa maneira, não pode o discurso de ódio ter a sua manifestação restringida, visto que isso significaria uma violação à Primeira Emenda. O Estado, entende, deve garantir a todos o direito de expressar suas ideias, independentemente do conteúdo veiculado, adotando uma postura de neutralidade na regulação das manifestações, mesmo as que sejam desprezíveis ${ }^{118}$.

\subsection{A decisão no Supremo Tribunal Federal do Brasil}

No Brasil, ao contrário do que ocorre nos Estados Unidos, não há uma jurisprudência consolidada. O Supremo Tribunal Federal só teve uma única oportunidade de se manifestar sobre o assunto: no julgamento de Habeas Corpus $n^{\circ}$ 82.424. O caso gerou grande discussão no Plenário da casa. É o que se passa a analisar.

No caso em tela, o sr. Siegfried Ellwanger foi condenado ao crime de racismo contra a comunidade judaica. Contra o paciente da ação, enquanto réu, foi ajuizada ação pelo Ministério Público no intuito de condená-lo, nos temos do artigo 20, caput, da Lei 7.716/89, com redação dada pela Lei 8.081/90 ${ }^{119}$,

\footnotetext{
${ }^{116}$ United States Court of Appeals, Seventh Circuit. Smith v. Collin [578 F.2d 1197]. Sentença em 22 de maio de 1978.

${ }^{117}$ A versão oficial da jurisprudência da Suprema Corte só é encontrada na versão impressa do United States Reports.

${ }^{118}$ SARMENTO, Daniel. A liberdade de expressão e o problema do hate speech. Revista de Direito do Estado. Rio de Janeiro: Renovar, 2006, p. 53-106.

${ }^{119}$ Artigo 20. Praticar, induzir ou incitar a discriminação ou preconceito de raça, cor, etnia, religião ou procedência nacional. Pena: reclusão de um a três anos e multa. In: BRASIL. Lei $\mathrm{n}^{\circ} \mathbf{7 . 7 1 6}$, de 5 de janeiro de 1989.
} 
por ter, na qualidade de escritor e de sócio da empresa "Revisão Editora Ltda.", editado, distribuído e vendido ao público obras anti-semitas de sua autoria e de outros escritores. Segundo a denúncia, tais obras literárias "abordam e sustentam mensagens anti-semitas, racistas e discriminatórias", com a finalidade de "incitar e induzir a discriminação racial, semeando em seus leitores sentimentos de ódio, desprezo e preconceito contra o povo de origem judaica" 120 .

Em primeira instância, o paciente foi absolvido pela juíza substituta Bernadete Coutinho Friedrich. De acordo com a magistrada, os textos não incitam, nem induzem à discriminação étnica do povo judeu. Em sede de recurso, porém, foi entendido pela $3^{\text {a }}$ Câmara Criminal do Tribunal de Justiça do Rio Grande do Sul que, o trabalho publicado pelo paciente tentava negar o holocausto, com o objetivo de "a intenção única do apelado é propagar uma realidade alicerçada em ideologia que chega às raias do fanatismo, sem base histórica provadamente séria". Nesse sentido, afirmou o desembargador José Eugênio Tedesco, revisor na ação, que:

"Sem qualquer dúvida, ao exame das obras editadas, distribuídas, escritas e comercializadas pelo apelado, do seu conjunto se extrai tranquilamente a intenção única de impor outra verdade, qual seja a execração de uma raça. Em cima de fatos históricos foi lançada uma outra pretensa realidade, sem qualquer escoro, no entanto, em elementos confiáveis, a não ser na imaginação dos escribas. (...) [É] inaceitável que se deixe de punir a manifestação da opinião, quando transparece evidente e cristalina a intenção de discriminar raça, credo, segmento social ou nacional, ainda que sob o manto de mera "revisão histórica"121.

Portanto, foi o paciente condenado pelo Tribunal de Justiça do Rio Grande do Sul, em sede de apelação, a dois anos de reclusão, com direito a sursis pelo prazo de quatro anos ${ }^{122}$. Alegando que a discriminação de cunho

\footnotetext{
${ }^{120}$ STF, HC n. 82.424-2/RS, Rel. Ministro Moreira Alves, Brasília, 17 set. 2003.

121 apud STF, HC n. 82.424-2/RS, Rel. Ministro Moreira Alves, Brasília, 17 set. 2003.

122 apud STF, HC n. 82.424-2/RS, Rel. Ministro Moreira Alves, Brasília, 17 set. 2003.
} 
anti-semita não se encontra abarcada pela discriminação de racismo, afirmou que, então, não estaria tal manifestação discriminatória sujeita à imprescritibilidade atribuída aos crimes por motivação de raça, estando, portanto, prescrito o crime pelo qual foi condenado em segunda instância. Assim, impetrou um habeas corpus perante o Superior Tribunal de Justiça, o qual foi denegado pela $5^{\text {a }}$ Turma do Tribunal. De acordo com o relator, Ministro Gilson Dipp "a condenação do paciente se deu por delito contra a comunidade judaica, não se podendo abstrair o racismo de tal comportamento - o qual restou claramente apontado na parte dispositiva e nos fundamentos da condenação ora impugnada" ${ }^{\prime 23}$.

Contra essa decisão do Superior Tribunal de Justiça, foi impetrado o habeas corpus ao Supremo Tribunal Federal, sob a mesma alegação de prescrição. Na corte constitucional não houve unanimidade quanto à posição a ser adotada, nem consenso em relação aos argumentos a sustentar cada tese.

No intuito de melhor compreensão a cerda dos argumentos levantados, o presente trabalho irá dividir por temas o que foi discutido. Assim sendo, primeiramente será apresentado o debate em torno da questão racial e, em seguida, se estaria, ou não, a discriminação de ódio protegida pelo direito constitucional à liberdade de expressão.

Quanto ao racismo, discutiu-se se estaria a comunidade judaica incluída no conceito de raça. O ministro relator do caso, Moreira Alves, em voto isolado, não incluiu no conceito de raça a discriminação contra a comunidade judaica, visto que a imprescritibilidade apresenta-se como elemento excepcional no ordenamento jurídico brasileiro, devendo ser aplicado de maneira restritiva. Segundo o ministro:

"O elemento histórico (...) converge para dar a "racismo" o significado de preconceito ou de discriminação racial, mais especificamente contra a raça negra. (...) dei-lhe interpretação restrita, para abarcar apenas as raças tradicionalmente tidas como tais: a negra, a amarela e a vermelha.

${ }^{123}$ apud STF, HC n. 82.424-2/RS, Rel. Ministro Moreira Alves, Brasília, 17 set. 2003. 
Se se adotar a exegese de que racismo diz respeito à discriminação contra pessoa de grupo humano com características culturais próprias, $\mathrm{o}$ que abarca qualquer grupo humano que se distinga de outro por sua cultura, ter-se-á que alguém que, aos dezoito anos de idade, cometer discriminação, pequena que seja, e passar abjurando esse seu comportamento até alcançar os oitenta anos, poderá, sessenta e dois anos após o fato, vir a ser condenado por ele a uma pena que é irrisória - entre dois e cinco anos de reclusão - em face da gravidade da imprescritibilidade" ${ }^{\prime 24}$.

Em sentido contrário, o ministro Maurício Corrêa afirmou que o antisemitismo está incluído no conceito de raça. Afirmou o ministro Mauricio Corrêa, seguido pelos demais, que a discriminação contra judeus é uma manifestação racista, não pelo fato de os judeus serem naturalmente uma raça, mas sim, por entender que aquele que assim age o faz com a crença de serem os judeus uma raça inferior e na intenção de subjugá-los. Em suas palavras:

"Os cientistas confirmam, assim, que não existe base genética para aquilo que as pessoas descrevem como raça, e que apenas algumas poucas diferenças distinguem uma pessoa de outra. A inexistência de raças não significa que todo mundo é igual. É que todo mundo é igualmente diferente. Com efeito, a divisão dos seres humanos em raças decorre de um processo político-social originado da intolerância dos homens. Disso resultou o preconceito racial. Consoante o conceito etnológico, por exemplo, raça é a coletividade de indivíduos que se diferencia por sua especificidade sociocultural, refletida principalmente na língua, religião e costumes; grupo étnico, como por exemplo a raça judia. (...) Fica assim explícito que tal conduta caracteriza ato de racismo, segundo as convicções de quem o pratica" ${ }^{, 25}$.

Quanto à liberdade de expressão, a discussão se desdobrou em dois momentos. Discutiu-se, em primeiro lugar, se o livro seria uma expressão discriminatória de raça e, em segundo lugar, se, sendo uma manifestação racista, estaria protegida pela liberdade de expressão. Enquanto houve divergência no Tribunal no tocante à primeira discussão, na segunda, houve uma unanimidade. Todos os ministros manifestaram-se a considerar o discurso

\footnotetext{
${ }^{124}$ STF, HC n. 82.424-2/RS, Rel. Ministro Moreira Alves, Brasília, 17 set. 2003.
} 
de ódio como forma de manifestação fora do alcance da proteção da liberdade de expressão. O ministro Gilmar Mendes bem definiu a posição da Corte:

"Talvez seja a liberdade de expressão, aqui contemplada a própria liberdade de imprensa, um dos mais efetivos instrumentos de controle do próprio governo. Para não falar que se constitui, igualmente, em elemento essencial da própria formação da consciência e de vontade popular. Não se desconhece, porém, que, nas sociedades democráticas, há uma intensa preocupação com o exercício de liberdade de expressão consistente na incitação à discriminação racial, o que levou ao desenvolvimento da doutrina do "hate speech" [, a qual] (...) não tem como objetivo exclusivo a questão racial. Nesse contexto, ganha relevância a discussão da medida de liberdade de expressão permitida sem que isso possa levar à intolerância, ao racismo, em prejuízo da dignidade humana, do regime democrático, dos valores inerentes a uma sociedade pluralista. Não se pode atribuir primazia absoluta à liberdade de expressão, no contexto de uma sociedade pluralista, em face de valores outros como os da igualdade e da dignidade humana. Daí ter o texto constitucional de 1988 erigido, de forma clara e inequívoca, o racismo como crime inafiançável e imprescritível (CF, art. 5\%, XLII), além de ter determinado que a lei estabelecesse outras formas de repressão às manifestações discriminatórias (art. $5^{\circ}, \mathrm{XLI}$ ). É certo, portanto, que a liberdade de expressão não se afigura absoluta em nosso texto constitucional. Ela encontra limites, também no que diz respeito às manifestações de conteúdo discriminatório ou de conteúdo racista. Trata-se, como já assinalado, de uma elementar exigência do próprio sistema democrático, que pressupõe a igualdade e a tolerância entre os diversos grupos"

Porém, embora a maioria do pleno tenha entendido por se considerar a edição do livro uma forma de prática do crime de racismo, os ministros Carlos Ayres Britto e Marco Aurélio decidiram em posição contrária. Enquanto o ministro Celso de Mello afirmou que "publicações - como as de que trata esta impetração - (...) extravasam os limites da indagação científica e da pesquisa histórica, degradando-se ao nível primário do insulto, da ofensa e, sobretudo,

\footnotetext{
${ }^{125}$ STF, HC n. 82.424-2/RS, Rel. Ministro Moreira Alves, Brasília, 17 set. 2003.

${ }^{126}$ STF, HC n. 82.424-2/RS, Rel. Ministro Moreira Alves, Brasília, 17 set. 2003.
} 
do estímulo à intolerância e ao ódio público pelos judeus"127, os ministro Carlos Ayres Britto e Marco Aurélio advogaram em sentido contrário.

De acordo com ambos os ministros, o caso em tela se trata de hipótese excludente prevista pelo inciso VIII do artigo $5^{\circ}$ da Constituição da República Federativa do Brasil ${ }^{128}$, no qual está garantido o direito à livre expressão quando o discurso contiver convicção política. Nas palavras dos próprios ministros, respectivamente:

"Três comportamentos, todavia, são especialmente normados como excludentes da abusividade. Comportamentos ditados por imperativos de consciência e que são, pela ordem com que a Lei Maior a eles se referiu: a crença religiosa, a convicção filosófica e a conviç̧ão política. (...) De conseguinte, atividade que ora se contém no fechado conteúdo programático de uma determinada agremiação partidária, ora se exprime numa concepção estritamente pessoal do modo optimum de estruturação e funcionalização da polis (espaço ideal de materialização das primárias relações entre governados e governantes e ainda entre os próprios Estados e Governos soberanos). na visão do próprio Siegfried enquanto escritor, o livro em causa é uma obra de pesquisa histórica. Quanto ao objeto central de estudo do livro, ou objeto específico da pesquisa acima referida, é o fato em si da última guerra mundial, ocorrida no período que vai de 1939 a 1945. Isto, numa perspectiva revisionista que tem por finalidade reabilitar a imagem do povo alemão, e retratar o quanto o Estado germânico sofreu de baixas humanas, prejuízos materiais e contratação territorial. Noutros termos, o paciente-escritor se esforça por demonstrar que toda a História da $2^{\circ}$ Grande Guerra foi contada pelos vencedores. (...) $\mathrm{O}$ estudo em causa pretende-se multifário o bastante para transitar pelos concomitantes domínios da liberdade de manifestação do pensamento e da produção intelectual, científica e de comunicação, afunilando para o campo da convicção política. Ou da convicção político-ideológica, mais exatamente" ${ }^{129}$.

O paciente restringiu-se a escrever e a difundir a versão da história vista com os próprios olhos. E assim o fez a partir de uma pesquisa científica,

\footnotetext{
${ }^{127}$ STF, HC n. 82.424-2/RS, Rel. Ministro Moreira Alves, Brasília, 17 set. 2003.

${ }^{128}$ Art. $5^{\circ}$ Todos são iguais perante a lei, sem distinção de qualquer natureza, garantindo-se aos brasileiros e aos estrangeiros residentes no País a inviolabilidade do direito à vida, à liberdade, à igualdade, à segurança e à propriedade, nos termos seguintes: (...) VIII - ninguém será privado de direitos por motivo de crença religiosa ou de convicção filosófica ou política, salvo se as invocar para eximir-se de obrigação legal a todos imposta e recusar-se a cumprir prestação alternativa, fixada em lei. In: In: BRASIL. Constituição da República Federativa do Brasil. Brasília, 5 out. 1988.

${ }^{129}$ STF, HC n. 82.424-2/RS, Rel. Ministro Moreira Alves, Brasília, 17 set. 2003.
} 
com os elementos peculiares, tais como método, objeto, hipótese, justificativa teórica, fotografias, documentos das mais diversas ordens, citações. Alfim, imaginando-se integrado a um Estado Democrático de Direito, acionou a livre manifestação, a convicção política sobre o tema tratado, exercitou a livre expressão intelectual do ofício de escritor e editor, conforme previsto nos incisos IV, VIII e XIII do artigo $5^{\circ}$ da Constituição Federal ${ }^{130}$.

Assim, defenderam os Ministros Carlos Ayres Britto e Marco Aurélio que o livro seria uma forma de manifestação incluída na proteção conferida à liberdade de expressão. Tais decisões basearam-se no fato de que o paciente teria se utilizado do livro como forma de apresentar uma visão política sobre a história e, por isso, mesmo que desprezível, estaria incluída a sua atitude nas hipóteses do inciso VIII do artigo $5^{\circ}$ da Constituição Federal.

Todavia, os próprios ministros afirmaram que, em se tratando de discurso de ódio, desvinculado de uma revisão histórica, não estaria a obra literária em discussão protegida. Então, pode-se perceber que divergem os ministros Carlos Ayres Britto e Marcos Aurélio dos demais apenas no tocando à inclusão dos livros os quais ensejaram o litígio judicial no conceito de discurso de ódio. Portanto, as manifestações de cunho odioso, por entendimento do Supremo Tribunal, não encontram, no Brasil, proteção sob o princípio da liberdade de expressão ${ }^{131}$.

O acima exposto foi apenas um panorama da forma como a jurisprudência lida com o discurso de ódio. Pode-se percebe que as manifestações odiosas tendem a ser reprimidas quando enfrentadas em um tribunal. Assim, pode-se afirmar que tanto o Brasil, quanto os sistemas interamericano e europeu adotam a crítica apresentada por Catherine A. MacKinnon. Os Estados Unidos, porém, conferem à liberdade de expressão um maior campo de atuação, promovendo uma maior divulgação e circulação de

\footnotetext{
${ }^{130}$ STF, HC n. 82.424-2/RS, Rel. Ministro Moreira Alves, Brasília, 17 set. 2003.

${ }^{131}$ STF, HC n. 82.424-2/RS, Rel. Ministro Moreira Alves, Brasília, 17 set. 2003.
} 
ideias, independentemente do conteúdo e, assim, chegando mais próximo ao modelo de um mercado livre de ideias pensado por Stuart Mill. 


\title{
CAPÍTULO 3. A IGUALDADE COMO PILAR DO MERCADO LIVRE DE IDÉIAS
}

\author{
Mais importante do que \\ chegar a uma boa solução é \\ provocar um bom debate \\ - Augusto Boal
}

A partir da discussão doutrinária apresentada no capítulo I e da solução jurisprudencial exposta no capítulo II, será feita no presente capítulo uma ponderação dos argumentos até aqui trazidos. Assim, será considerada a crítica de MacKinnon aos problemas atuais de se assumir um mercado livre de ideias sem que haja uma ação para a promoção da igualdade. Em seguida, será contestada a solução da própria autora no intuito de demonstrar que, apesar de suas precisas análises em relação aos problemas trazidos pelo discurso de ódio, a proibição legal não se mostra uma resposta adequada à resolução do conflito, levando-se em conta a interdisciplinaridade do problema exposto.

Assim sendo, faz-se fundamental reconhecer a precisão da análise de Catherine A. MacKinnon sobre os problemas trazidos pelo discurso de ódio. Ao afirmar, como já mencionado anteriormente, que tais manifestação têm como objetivo silenciar determinados grupos sociais, a autora concluiu que elas acabam por tornar falso o argumento que as protege. Isto é, o mercado livre de ideias é o espaço em que todas as opiniões são, em tese, garantidas e, por isso, retirar-lhe o discurso de ódio é torna-lo deficiente. Porém, na linha de argumentação de MacKinnon, as manifestações de cunho odioso produzem efeito tal em a quem é dirigida, que esta vê-se silenciada e, dessa maneira, o mercado de ideias não se torna menos deficiente.

Na mesma linha de pensamento, o ministro do Supremo Tribunal Federal brasileiro, Carlos Ayres Britto, no julgamento apresentado no capítulo anterior, também se posicionou sobre o tema. De acordo com ele, os efeitos da externalização 
de um discurso odioso são de tamanha repercussão sobre o indivíduo a quem é direcionado, que o impossibilita de exercer a sua cidadania e de desenvolver sua personalidade:

"Esse modo tão acabrunhante quanto desarrazoado de tratar um ser humano é de tamanha gravidade que o discriminado é como que forçado a se sentir padecente de um déficit de dignidade. Ou de cidadania. Como se pertencesse a um subgrupo ou a uma sub-raça. Amesquinhado, não no que ele tem, mas no que ele é. Experimentando, por conseguinte, um inexplicável sentimento de culpa - espécie terrível de pecado original social - e fazendo-o gemer de uma revoltante dor moral. Por vezes mais incômoda que a própria dor física" ${ }^{, 132}$.

Desse modo, pode-se concluir que a dor causada ao destinatário de tais manifestações, como afirmaram o ministro, acima, e Catherine MacKinnon, no primeiro capítulo do presente trabalho, tem o caráter silenciador. Ou seja, tem por objetivo impedir que os membros de um determinado grupo subjugado tenham voz suficiente para exporem-se e serem inseridos no debate público de ideias, gerando problemas na efetivação da liberdade de expressão como direito constitucionalmente garantido.

A Relatoria para a Liberdade de Expressão da Comissão Interamericana de Direitos Humanos já se manifestou sobre o assunto. De acordo com o referido órgão, para que sejam os direitos humanos de um indivíduo assegurados é indispensável o exercício da liberdade de expressão de maneira ampla e irrestrita, pois "[o] silêncio é o melhor aliado para perpetuar os abusos e desigualdades" praticados contra os que se pertencem a um grupo socialmente oprimido ${ }^{133}$. E mais, já afirmou que é dever do Estado procurar eliminar todo tipo de medidas discriminatórias ao indivíduo de uma participação plena na vida política, econômica, pública e social de seu país ${ }^{134}$.

\footnotetext{
${ }^{132}$ STF, HC n. 82.424-2/RS, Rel. Ministro Moreira Alves, Brasília, 17 set. 2003.

${ }^{133}$ IIDH. Libertad de expressión en las Américas. Los cinco primeiros informes de la Relatoría para la Libertad de Expressión. San José: Instituto Interamericano de Derechos Humanos, 2003, p. 168-169.

${ }^{134}$ CIDH. Informe Anual de la Relatoría para la Libertad de Expresión, 2002, cap. IV, par. 13.
} 
Existem, portanto, barreiras ao pleno exercício da liberdade de expressão. Visto que o mercado livre de ideias pressupõe uma igualdade para que o debate possa ocorrer, uma condição de desigualdade entre os indivíduos os quais compõe a sociedade apresenta-se como um obstáculo ao pleno desenvolvimento desse debate livre, no qual todas as ideias seriam expostas. Isso significa dizer que, como afirmou Cass Sunstein, "nós não sabemos como seria um mercado de ideias que funcione bem" ${ }^{\prime 135}$, pois a condição de desigualdade na qual se encontram determinados setores da sociedade os impede de exercer seus direitos fundamentais, dentre eles, a liberdade de expressão.

Dessa maneira, a polarização alegada por MacKinnon, entre liberdade de expressão e igualdade, embora não seja necessária, torna-se real. E, assim, emerge dessa dicotomia um conflito entre dois princípios constitucionalmente garantidos, os quais, quando enfrentados, devem ser ponderados a fim de se tentar, ao máximo, preservá-los ${ }^{136}$. Tal ponderação, realizada no caso brasileiro supra analisado, exige que uma avaliação, a quem lhe for incumbido, de três critérios: (i) a adequação da medida tomada, ou seja, se tal solução é suficiente para que sejam atingidos os objetivos finais; (ii) a necessidade da supressão de um princípio em favor de outro; e (iii) a proporcionalidade em sentido estrito da restrição ${ }^{137}$.

Quanto ao critério da adequação, em relação ao caso problematizado no presente trabalho, faz-se necessário avaliar se a proibição do discurso de ódio é medida adequada para garantir uma igualdade aos indivíduos pertencentes a grupos ofendidos. Em um primeiro momento, pode parecer que sim, já que o fator silenciador de tais pessoas não mais pode ser proferido. Entretanto, a prórpia União Européia, cuja Corte jurisdicional, como apresentado no capítulo

\footnotetext{
${ }^{135}$ SUNSTEIN, Cass R. Free speech now. In. AMAR, Vikram David (Org). The First Amendment Freedom of Speech: its constitutional history and the contemporary debate. New York: Prometheus Books, 2009, p. 111.

${ }^{136}$ SUNSTEIN, Cass R. Free speech now. In. AMAR, Vikram David (Org). The First Amendment Freedom of Speech: its constitutional history and the contemporary debate. New York: Prometheus Books, 2009, p. 103.
} 
anterior, possui jurisprudência no sentido de coibir o discurso de ódio, considerando-o fora do alcance da proteção da liberdade de expressão, já se mostrou preocupada com o aumento dos crimes de motivação odiosa na Europa. Em relatório sobre o tema, afirmou que

"Apesar dos melhores esforços e compromissos dos Estados-Membros da União europeus (UE) para combater a discriminação e a intolerância, incluindo manifestações de crimes de ódio, há indícios de que a situação em que a UE não está a melhorar. Pelo contrário, nos últimos anos, temos assistido continuaram e renovou as violações dos direitos fundamentais das pessoas que vivem dentro da UE - pelo menos não de todo o seu direito à dignidade humana - através de abuso verbal, agressões ou assassinatos motivados por preconceito" ${ }^{138}$.

Por que, então, os crimes de ódio estão crescendo, se tais manifestações são legal e juridicamente reprimidas? Pois o discurso de ódio não de esgota na fala. Como assinalou Judith Butler, há outras maneiras pelas quais o discurso odioso age na sociedade sem nos darmos conta e essas formas de manifestações odiosas, talvez mais perniciosas e silenciadoras do que a edição de um livro, não são alcançadas pelas leis e pelos tribunais ${ }^{139}$.

Assim sendo, faz-se mister entender, em um primeiro momento, que o ódio não se manifesta apenas através da fala. Ou seja, o discurso não se realiza apenas através da fala em sentido estrito, mas também pode ocorrer na forma de ações, como no caso do estupro, afirmou Catherine MacKinnon, o qual "é um código humano de dominação" ${ }^{140}$. Segundo a própria autora, o discurso odioso contra as mulheres, por exemplo, ocorre "sob a bandeira da privacidade", a qual é definida como área imprópria de atuação do Estado e,

\footnotetext{
${ }^{137}$ STF, HC n. 82.424-2/RS, Rel. Ministro Moreira Alves, Brasília, 17 set. 2003.

${ }^{138}$ União Européia. Making hate crimes visible in the European Union: acknowledging victims' rights, Luxemburgo, 2012.

${ }^{139}$ BUTLER, Judith. Excitable speech: a politics of the performative. New York: Routledge, 1997, p. 2.

${ }^{140}$ MACKINNON, Catherine. Are women human? And other international dialogues. Cambridge: Harvard University Press, 2007, p. 230.
} 
consequentemente, deixando de proteger quem deveria ser protegida ${ }^{141}$. De tal modo, tanto a autora, quanto o ministro Moreira Alves apresentam ilustrações de formas de manifestações odiosas as quais não são proibidas e, muitas vezes, sequer são consideradas manifestações de cunho odioso. De acordo com a autora:

"Este movimento faz notar que os homens geralmente não são tratados dessa maneira. Os homens não têm jogado gasolina sobre eles e acendeu e tê-lo chamado de um acidente de cozinha. Os homens não têm os órgãos genitais cortados e dilacerada por isso que o HIV é ainda mais provável e as relações sexuais é insuportável ou sem prazer. Mas isso não limita as mulheres a imitar os homens. Ninguém exige o direito igual para cobrir os homens com gasolina e acendê-lo. Coloque conceitualmente, as mulheres em todos os lugares perceber que a própria diferença não significa ser de segunda classe. Inferioridade imposta faz. Este movimento mostra um senso que o domínio socialmente organizado é o problema, bem como critica seus excessos. Mulheres de toda parte percebe tanto que os homens têm muito poder e que o poder é baseado em coisas erradas, organizado de forma errada. As mulheres querem o poder redistribuído como é redefinida redistribuído para as mulheres, pois é redefinido para que alguém nem sempre é acima de outra pessoa, em um arranjo de uma só vez forçado e sexualizada, definindo quem pode fazer isso como um homem e um ser superior" ${ }^{\prime 142}$.

Segundo o Ministro:

"considerados os tipos penais da legislação ordinária relativos à discriminação, quando motivados pela raça, que serão eles imprescritíveis, como, por exemplo, o de impedir o acesso ou recusar atendimento em salões de cabeleireiros, barbearias, termas, casas de massagem, ou estabelecimentos com finalidades semelhantes; ou então, negar ou impedir a inscrição ou ingresso de aluno em estabelecimento de ensino público ou privado de qualquer grau ${ }^{143}$.

\footnotetext{
141 MACKINNON, Catherine. Are women human? And other international dialogues. Cambridge: Harvard University Press, 2007, p. 23.

142 MACKINNON, Catherine. Are women human? And other international dialogues. Cambridge: Harvard University Press, 2007, p. 108.

${ }^{143}$ STF, HC n. 82.424-2/RS, Rel. Ministro Moreira Alves, Brasília, 17 set. 2003.
} 
Em um segundo momento, contudo, percebe-se que o discurso não transcende apenas a fala em sentido estrito, mas extrapolam os indivíduos, impregnando-se nas instituições sociais. Como a própria MacKinnon reconheceu ao tratar do racismo de 1950 nos Estados Unidos: "o racismo institucionalizado teve dois sistemas aparentemente distintos, até mesmo opostos, a fim de validá-lo. No Sul, esse racismo tinha a autoridade da lei ${ }^{144}$. A própria Comissão Interamericana reconhece que

"Em algumas ocasiões, os casos de violência doméstica denunciados perante as forças policiais tem sido tratados como ofensas menores, dissuadindo a mulher de denunciar futuros abusos por suceder dentro do marco de sua vida privada. Em alguns casos, a força policial se tem recusado a processar estas denuncias ou a oferecer medidas cautelares para a proteção da vitima. Tais ações submetem a mulher a um rol subordinado e degradante, obstruindo sua capacidade de expressão e ação e perpetuando o círculo de violência, abuso e discriminação" ${ }^{145}$.

As repressões jurídicas e legais, portanto, não se apresentam como medidas eficientes na promoção da igualdade, pois não têm o condão de chegar às profundezas do problema. Assim, a partir do acima exposto e, como bem afirmou Daniel Sarmento, pode-se perceber que o discurso de ódio não é um fenômeno isolado e pontual na sociedade. Pelo contrário, constitui a própria estrutura social, permeando "os seus extratos mais profundos e desempenha[ndo] um papel importante na definição de uma série de práticas que vivenciamos no nosso dia-a-dia, sem nos darmos conta das suas raízes espúrias" ${ }^{\text {146 }}$. Isso significa dizer que não é apenas uma questão jurídica, mas sim, um problema a ser enfrentado a partir de um diálogo entre as diversas formas de saber.

\footnotetext{
${ }^{144}$ DWORKIN, Andrea \& MACKINNON, Catherine A. Pornography and civil rights - a new day for women's equality, 1988. Disponível em http://www.nostatusquo.com/ACLU/dworkin/other/ordinance/ newday/T1a.htm Acesso em 10.05.2013.

${ }^{145} \mathrm{IIDH}$, Libertad de expressión en las Américas. Los cinco primeiros informes de la Relatoría para la Libertad de Expressión. San José: Instituto Interamericano de Derechos Humanos, 2003, p. 170-172.

${ }^{146}$ SARMENTO, Daniel. A liberdade de expressão e o problema do hate speech. Revista de Direito do Estado. Rio de Janeiro: Renovar, 2006, p. 53-106.
} 
Pode-se, de tal modo, concluir que a proibição do discurso de ódio, a partir de uma perspectiva prática, não se caracteriza como a medida mais adequada, pois não resulta na diminuição da incidência do ódio. Stuart Mill explica que isso ocorre, uma vez que "as restrições em questão afetam apenas a parte de conduta que a sociedade é competente para reprimir, e estão errados apenas porque eles realmente não produzem os resultados que se deseja produzir por eles" ${ }^{\prime 47}$. Nesse sentido, Michel Foucault afirma que enquadrar a questão do poder, na qual o discurso faz-se fundamental, unicamente em termos de legislação é inadequado, pois o "poder é mais complicado, muito mais denso e difuso que um conjunto de leis ou um aparelho de Estado"148. Explica o autor:

"Ora, me parece que a noção de repressão é totalmente inadequada para dar conta do que existe justamente de produtor no poder. Quando se define os efeitos do poder pela repressão, tem-se uma concepção puramente jurídica deste mesmo poder; identifica-se o poder a uma lei que diz não. O fundamental seria a força da proibição. Ora, creio ser esta uma noção negativa, estreita e esquelética do poder que curiosamente todo mundo aceitou. Se o poder fosse somente repressivo, se não fizesse outra coisa a não ser dizer não você acredita que seria obedecido? O que faz com que o poder se mantenha e que seja aceito é simplesmente que ele não pesa só como uma força que diz não, mas que de fato ele permeia, produz coisas, induz ao prazer, forma saber, produz discurso. Deve-se considerá-lo como uma rede produtiva que atravessa todo o corpo social muito mais do que uma instância negativa que tem por função reprimir ${ }^{149}$.

Assim sendo, a partir do exposto, a repressão legal ao discurso de ódio mostra-se insuficiente. Além de afetar o direito constitucionalmente protegido da liberdade de expressão, acaba por não ser uma solução adequada para resolver o problema ao qual se propõe e, dessa maneira, não preenche o

\footnotetext{
${ }^{147}$ MILL, John Stuart. On liberty. New York: Dover Publications Inc., 2002, p. 80.

${ }^{148}$ FOUCAULT, Michel. Resumo dos cursos do Collège de France (1970-1982). Rio de Janeiro: Jorge Zahar Ed., 1997, p. 11.

${ }^{149}$ FOUCAULT, Michel. Microfísica do poder. $25^{\mathrm{a}}$ ed. São Paulo: Graal, 2012, p. 44-45.
} 
primeiro critério da ponderação de princípios acima apresentado, a adequação, tornando desnecessária a análise dos demais.

Então, surge uma nova questão: como garantir a igualdade sem que a expressão seja reprimida. Ou seja, como os grupos socialmente subjugados poderiam conquistar a igualdade e, dessa maneira, tornar real o mercado livre de ideias, hoje deficiente. Visto que o direito, em matéria de discurso odioso, não é suficiente na promoção da igualdade, impõe-se fundamental buscar a resposta em outros campos sociais.

Longe de tentar esgotar a discussão acerca do problema ora exposto, serão a seguir apresentadas, a título ilustrativo, algumas hipóteses a partir das quais pode-se pensar em um processo de conquista de espaço no debate social. Em primeiro lugar, será apresentada a internet como forma de facilitação da circulação de informações e de ideias e, portanto, de propagação dos pontos de vista contrários aos dos meios de comunicação dominantes. Em segundo lugar, será explicada a maneira pela qual o Teatro Fórum, modalidade do Teatro do Oprimido, é realizado e como pode, ou deve, ser ele utilizado como instrumento para se repensar os problemas sociais. Em terceiro, e por último, se utilizará do movimento das Mães de Acarí a fim de exemplificar a tomada de consciência e da conquista de voz.

A internet vem inserindo-se na vida social como potencial instrumento na fomentação do direito à liberdade de expressão e de informação ${ }^{150}$. A Comissão Interamericana de Direitos Humanos afirma ser a internet uma poderosa arma para se dar voz a quem não tem e de se difundir ideias as quais não seriam difundidas pelos meios de comunicação tradicionais. Assim afirmou:

\footnotetext{
${ }^{150}$ CIDH. Mecanismos Internacionales Para la Promoción de la Libertad De Expresión: Declaración Conjunta - Desafíos a la Libertad de Expresión en el Nuevo Siglo. In: Informe Anual 2012. Informe de la Relatóría para la Libertad de Expresión. OEA/Ser.L/V/II.147. Doc. 1. 5 de março de 2013, Anexo IV.
} 
O Relator para a Liberdade de Expressão considera que a Internet constitui um instrumento que tem a capacidade de fortalecer o sistema democrático, contribuir ao desenvolvimento econômico dos países da região, e fortalecer o pleno exercício da liberdade de expressão. Internet é uma tecnologia sem precedentes na história das comunicações que permite o rápido acesso e transmissão a uma rede universal de informação múltipla e variada. Internet é um meio com grandes possibilidades porque permite a participação aberta dos indivíduos nos processos de discussão e intercâmbio de informação sobre temas de seu interesse. $\mathrm{O}$ alcance global da Internet permite que os indivíduos se informem e comuniquem instantaneamente sem limites geográficos e sem distinções por razão de raça, sexo, religião ou origem social. Maximizar a participação ativa da cidadania através do uso da Internet contribui ao desenvolvimento político, social, cultural e económico das nações, fortalecendo a sociedade democrática. A sua vez, a Internet, tem o potencial de ser um aliado na promoção e difusão dos direitos humanos e dos ideais democráticos e um instrumento de importante envergadura para o acionar de organizações de direitos humanos pois por sua velocidade e amplitude permite transmitir e receber de forma imediata condiciones que afetam os direitos fundamentais dos indivíduos em diferentes regiões ${ }^{151}$.

De tal modo, a internet se apresenta como uma importante forma de difusão da informação, facilitando tanto a recepção quanto a manifestação de ideias. Portanto, pode ser entendido como instrumento fundamental a ser utilizado no combate às desigualdades que envolvem a sociedade. Em um sentido diferente, o Teatro Fórum também é uma forma de se dar voz a quem a sociedade tem negado, mas, ao invés de trabalhar com o momento da divulgação de ideias, preocupa-se com o momento anterior no qual o indivíduo já tem consciência do problema que o cerca, mas não enxerga meios para superá-lo.

Assim, o Teatro Fórum produz-se a partir de um problema concreto utilizando-se dos próprios protagonistas reais da opressão na produção de uma peça. Reproduz-se uma situação cotidiana em cena, tendo-se como base fatos

\footnotetext{
${ }^{151} \mathrm{IIDH}$, Libertad de expressión en las Américas. Los cinco primeiros informes de la Relatoría para la Libertad de Expressión. San José: Instituto Interamericano de Derechos Humanos, 2003, p. 172-173
} 
reais, na qual oprimido e opressor se confrontam com o objetivo de defenderem seus desejos e seus interesses. O oprimido, em uma representação ao que acontece na realidade, fracassa e o Curinga (o facilitador do Teatro do Oprimido) estimula o público a entrar em cena, substituir o protagonista e oferecer uma nova saída para o problema, apresentando, assim, para o oprimido uma nova perspectiva da situação ${ }^{152}$. Cilene Canda explica:

O problema, ou o conflito, deve ser claro e apresentar-se como uma pergunta a ser levada ao fórum. Boal ressalta a clareza da pergunta que norteará a discussão, afirmando que o desejo do oprimido deve ficar evidente para todos; só a partir disso, é possível construir um fórum de debate - político e estético! Com o término do anti-modelo, o curinga questiona o público a respeito do que se apresentou no palco e convidao a entrar em cena e a propor novos esquemas possíveis de atuação do oprimido para a realização do seu desejo no ato cênico e para, principalmente, superar ou amenizar a opressão ali apresentada. Independente de obter um resultado satisfatório, o espect-ator estará experimentando o espaço da atuação estética e política, como um ensaio para a vida social. No fórum, o sujeito está testando concretamente, ainda que de modo metafórico, as possibilidades de atuar no cotidiano. Salientamos que o mais importante não é solucionar o problema, destruir a opressão ou realizar o desejo do oprimido; o que importa é o debate estético e a busca por alternativas, revelando que a questão implica em várias formas de atuação do oprimido e não somente uma intervenção no anti-modelo. Todo problema sugere meios diferentes de intervenção e de resolução; anunciar apenas uma alternativa possível é também uma atitude autoritária. Não se procura a melhor solução, mas conhecer mecanismos de poder presentes na situação, experimentando e buscando saídas, do ponto de vista do protagonista. As alternativas são analisadas pela platéia, cujas pessoas, ativadas - para usar um termo de Boal -, se transformam de espectadores em espect-atores - aqueles que vêem e agem. Esta questão é, ainda, endossada pelo próprio Boal, ao tratar sobre os propósitos do Teatro-fórum: "mais importante do que chegar a uma boa solução é provocar um bom debate. Na minha opinião, o que conduz à auto-ativação dos espect-atores é o debate, não a solução que porventura possa ser encontrada" ${ }^{\text {"153 }}$.

152 A definição oficial, encontrada na página virtual do Teatro do Oprimido. Disponível em http://ctorio.org.br/novosite/arvore-do-to/teatro-forum/. Acesso em 11 de junho de 2013. 
Dessa maneira, o Teatro Fórum faz com que o sujeito oprimido quebre o silencio e conquiste a sua voz. A partir de uma nova perspectiva, descoberta em conjunto com seu opressor, aquele que ocupava uma posição socialmente subjugada passa a refletir sobre o seu papel na sociedade e a repensar a maneira de vive-lo, transformando-se em ator social e deixando de lado o seu caráter de espectador.

Por fim, a terceira hipótese a ser apresentada no intuito de ilustrar formas políticas de se conferir igualdade a indivíduos socialmente subordinados é a da formação de movimentos sociais, aqui representada pelas Mães de Acari. A década de 90 na cidade do Rio de Janeiro foi marcada por diversas chacinas cometidas por policiais civis e militares contra meninos negros e pobres ${ }^{154}$. Apesar da dor de perder um filho, as mulheres, mães dos meninos assassinados, em uma forma de tomada de consciência se uniram no intuito de tornar social uma questão que, até então, tomavam como particulares: a prática ilegítima da violência de agentes do Estado brasileiro ${ }^{155}$. Explica Suely Almeida:

A mobilização permanentes de mulheres na cena publica contra a impunidade pela morte de seus filhos e familiares, assim como manifestações de solidariedade em outros julgamentos similares, permite a politização do problema. Assim, nega-se que se trata de problemas episódicos, de natureza privada, abstraídos do seu contexto histórico, possibilitando sua representação enquanto problema de interesse público, o que favorece a alteração de uma correlação de forcas determinada. Ademais, as ações das mulheres em questão, em conjunto com outros grupos de pressão, têm potencial para a mobilização da opinião pública contra a lógica de julgamento dos crimes cometidos contra membros das camadas populares por representantes do poder instituído. A invasão policial praticada contra integrantes das camadas populares, em suas próprias casas ou enquanto

153 CANDA, Cilene Nascimento. Teatro-fórum: propósitos e procedimentos. Urdimento. n. 18. mar/2012, p. 121-123.

${ }^{154}$ ALMEIDA, Suely Souza de. Violência urbana e constituição de sujeitos políticos. In: PEREIRA, Carlos Alberto Messeder et al. Linguagens da violência. Rio de Janeiro: Rocco, 2000, p. 97.

${ }^{155}$ ALMEIDA, Suely Souza de. Violência urbana e constituição de sujeitos políticos. In: PEREIRA, Carlos Alberto Messeder et al. Linguagens da violência. Rio de Janeiro: Rocco, 2000, p. 98. 
dormem, expressa, de forma extrema e dramática, a invasão do poder público na vida privada. Estes episódios produziram impactos profundos nos desenhos das estruturas familiares, provocando rupturas e levandoas a reinventar a lógica da solidariedade - comum às famílias das camadas populares, enquanto estratégia de sobrevivência necessária à sua reprodução cotidiana. Esta lógica redefine valores e subordina projetos individuais aos interesses e necessidades do grupo familiar. As práticas familiares incorporam-se tais fatores externos, públicos, que impulsionam o subjetivação das mulheres enquanto tecelãs das relações familiares - condição que lhes levará a frequentar a cena pública e a reinventar direitos. (...) Em outras palavras, trata-se da constituição de sujeitos políticos, capazes de tematizar questões centrais à afirmação de sua identidade enquanto classe ou categoria, o que não exclui - ao contrario, supõe - a vivência de suas singularidades. Assim, as categorias público e privado estão longe de ser estruturalmente dicotômicas, embora seja esta a construção ideológica necessária à manutenção das relações sociais hegemônicas, profundamente hierarquizadas ${ }^{156}$.

Neste sentido, a experiência do autoritarismo estatal serviu de base para a construção da sociabilidade política dessas mulheres, as quais criam um espaço no debate público, mostrando-se visíveis. Nos dizeres de Suely Almeida, "esta é uma concepção que subverte a lógica do espaço político clássico, exigindo que se reinventem novas bases para fazer política ${ }^{157}$.

A partir de todo o exposto ao longo dos capítulos, pode-se perceber o debate sobre liberdade de expressão e discurso de ódio traduz-se em tema controverso e complexo. Tendo-se isso em vista, não pretendeu o presente trabalho esgotá-lo, nem apresentar-lhe uma solução. Apenas introduzi-lo, problematizando a teoria clássica de Stuart Mill, a solução teórica de Catherine A. MacKinnon e a abordagem jurídica da corte constitucional brasileira e dos sistemas interamericano e europeu de proteção aos direitos humanos e

\footnotetext{
${ }^{156}$ ALMEIDA, Suely Souza de. Violência urbana e constituição de sujeitos políticos. In: PEREIRA, Carlos Alberto Messeder et al. Linguagens da violência. Rio de Janeiro: Rocco, 2000, p. 105-109.

${ }^{157}$ ALMEIDA, Suely Souza de. Violência urbana e constituição de sujeitos políticos. In: PEREIRA, Carlos Alberto Messeder et al. Linguagens da violência. Rio de Janeiro: Rocco, 2000, p. 97.
} 
brasileiro, trazendo o modelo americano como um contra ponto à perspectiva dominante em tais tribunais. Em resposta, concluiu que a abordagem jurídica é insuficiente ao tratamento dessa questão, sendo necessária a abordagem interdisciplinar. 


\section{CONCLUSÃO}

O presente trabalho se desenvolveu com o objetivo problematizar a proibição do discurso de ódio em nome da igualdade. Assim, no primeiro capítulo, no foi apresentada a discussão teórica sob a perspectiva da teoria de John Stuart Mill do mercado livre de ideias, com a contraposição de Catherine A. MacKinnon. Em consonância com a primeira perspectiva, o discurso de ódio é peça fundamental para a engrenagem do mercado livre; e já a segunda defende que a inclusão do discurso de ódio na proteção da liberdade de expressão inviabilizaria o mercado livre de ideias, visto que o discurso de ódio silenciaria a voz dos membros dos grupos alvos de tais manifestações.

Assim sendo, pode-se entender pela teoria de Stuart Mill que o discurso de ódio é fundamental, pois (i) assumindo-se ter esse um caráter falacioso, funciona como um contra ponto à verdade já estabelecida, conferindo-lhe maior validade; (ii) fortalece a democracia, visto que possibilita povo a conhecer e entender a ideia contra a qual se luta, na promoção de uma sociedade mais igualitária; (iii) incentiva o desenvolvimento dos indivíduos, os quais, a partir do momento em que são confrontados com tais ideias, serão forçados a refletir sobre elas e a escolher o modelo de sociedade no qual quer viver; e (iv) impõe a todos os indivíduos a capacidade de tolerar as ideias, inclusive as que mais despreze, tornando-os seres mais flexíveis e capazes de conviver com as diferenças

Em sentido contrário, MacKinnon conclui que o discurso de ódio não é fundamental ao mercado livre de ideias, mas sim, o que lhe torna falso. Percebe, então, que a manifestação de cunho odioso (i) não auxilia na busca pela verdade, já que aqueles a quem se dirige o ódio encontram-se em situação de subordinação tal, que não possuem condições de expor suas opiniões e, portanto, não atingindo os requisitos definidos por Stuart Mill; (ii) não fortalece a democracia, pois os indivíduos não são iguais em condições para revindicar seus direitos; (iii) não incentiva o desenvolvimento da 
individualidade, pois a finalidade do discu7rso de ódio é minar com a subjetividade das pessoas pertencentes ao grupo ao qual a ofensa é dirigida; e (iv) não estimula a tolerância por todos, pois só a impõe a quem se encontra subordinado pelo discurso de ódio, visto que este já é, em si, a materialização da intolerância.

Em um segundo momento, foi apresentada a divergência jurisprudencial. Coma a exposição do posicionamento dos sistemas interamericano e europeu de proteção aos direitos humanos, em âmbito internacional, e das cortes constitucionais dos Estados Unidos e do Brasil, em sede de direito comparado. A partir do que foi apresentado, pode-se observar que, em sua maioria, os tribunais tendem a proibir o discurso de ódio, considerando-o fora do escopo da liberdade de expressão. Embora não se manifestado em caso específico sobre o tema, o sistema interamericano de direitos humanos deixa claro em informes, relatórios e opiniões consultivas o seu posicionamento acerca do tema. Assim sendo, têm entendido os órgãos do sistema interamericano que o discurso de ódio, por se tratar de manifestação de cunho discriminatório, não está esse protegido pelas normativas interamericanas. Na mesma linha a Corte Europeia de Direitos Humanos também não inclui o discurso de ódio no rol das manifestações a serem protegidas, por considera-las abuso à liberdade de expressão.

Em posição semelhante, o Supremo Tribunal Federal do Brasil entendeu que o direito constitucional da liberdade de expressão não engloba o discurso de ódio. Embora tenha havido divergência quanto à inclusão, ou não, da obra literária no conceito de discurso de ódio, todos os ministros acordaram que, em se tratando de manifestação de cunho odioso, não estaria a obra protegida pela proteção conferida às expressões.

Em linha oposta, a Suprema Corte norte-americana confere uma posição privilegiada à liberdade de expressão, incluindo em seu conceito o discurso de ódio. de acordo com o referido tribunal, não pode o discurso de ódio ter a sua 
manifestação restringida, visto que isso significaria uma violação à Primeira Emenda, devendo o Estado garantir a todos o direito de expressar suas ideias, independentemente do conteúdo veiculado, adotando uma postura de neutralidade na regulação das manifestações, mesmo as que sejam desprezíveis.

A partir desse panorama das discussões que envolvem o problema do discurso de ódio e sua restrição, ou não, o terceiro capítulo dedicou-se a demonstrar que a polarização entre igualdade e liberdade de expressão não é necessária. Dessa maneira, questionou a eficácia da proibição legal a tais manifestações e buscou apresentar meios pelos quais a igualdade pudesse ser atingida sem que o discurso tivesse que ser proibido de ser proferido. Para tanto, apresentou a internet como um importante meio de democratização da circulação de informação, visto que é um espaço livre. Ainda, trouxe os exemplo do Teatro Fórum e da Mães de Acari como meio e como exemplo, respectivamente, de maneiras pelas quais os indivíduos podem quebrar o silêncio e tomar seus lugares no palco das discussões.

Assim, os autores cujas teorias foram apresentadas no primeiro capítulo revelaram-se fundamentais na condução do debate. Tendo-se como base a noção de mercado livre de ideias, trazido por Stuart Mill, e os problemas reais produzidos pelo discurso de ódio, como bem analisou MacKinnon, pôde-se desenvolver um panorama das deficiências causadas pela forma como é tratado o tema nos tribunais analisados no segundo capítulo, chegando-se à percepção de que não há, na realidade, um mercado livre de ideias, mas que, porém, a proibição de manifestações odiosas não é meio adequado para se garantir a igualdade. Ou seja, conclui-se que a dicotomia liberdade-igualdade existe, porém, não é inerente a uma sociedade democrática, podendo ser superada por processos sociais e políticos pelos quais os indivíduos adquirem voz perante a sociedade. 


\section{BIBLIOGRAFIA}

AMAR, Vikram David (Org). The First Amendment Freedom of Speech: its constitutional history and the contemporary debate. New York: Prometheus Books, 2009

ALMEIDA, Suely Souza de. Violência urbana e constituição de sujeitos políticos. In: PEREIRA, Carlos Alberto Messeder et al. Linguagens da violência. Rio de Janeiro: Rocco

BRUGGER, Winfried. Proibição ou proteção do discurso do ódio - Algumas observações sobre o direito alemão e o americano. Direito Público. Porto Alegre, n. 15, p. 118, jan./mar. 2007

BUTLER, Judith. Excitable speech: a politics of the performative. New York: Routledge, 1997

CANDA, Cilene Nascimento. Teatro-fórum: propósitos e procedimentos. Urdimento. n. 18. mar/2012CIDH. Informe Anual de la Relatoría para la Libertad de Expresión, 2002.

CIDH. Informe Anual 2012. Informe de la Relatóría para la Libertad de Expresión. OEA/Ser.L/V/II.147. Doc. 1. 5 de março de 2013

Corte Européia. Caso Handyside v. United Kingdom. Sentença em 7 dez. 1976 Caso Middelburg, Van Der Zee And Het Parool B.V. v. The Netherlands. Sentença em 21 out. 1998

22 out. 2007 . Caso Lindon, Otchakovsky-Laurens and July v. France, Sent. 1994 . Caso Otto-Preminger-Institut v. Austria. Sentença em 20 set.

Corte IDH. La colegación obligatória de periodistas. Opinião Consultiva OC5/85, de 13 de novembro de 1985

. Caso Herrera Ulloa v. Costa Rica. São José, Costa Rica. Sentença em 2 de julho de 2004 maio de 2008

. Caso Kimel v. Argentina. São José, Costa Rica. Sentença em 2 de . Caso Vélez Loor v. Panamá. São José, Costa Rica. Sentença em 23 de novembro de 2010 
DWORKIN, Andrea \& MACKINNON, Catherine A. Pornography and civil rights - a new day for women's equality, 1988. Disponível em http://www.nostatusquo.com/ACLU/dworkin/ other/ordinance/newday/T2c.htm. Acesso em 10.05.2013

FOUCAULT, Michel. Microfísica do poder. 25ª ed. São Paulo: Graal, 2012

IIDH. Libertad de expresión en las Américas. Los cinco primeros informes de la Relatoría para la Libertad de Expresión. San José: Instituto Interamericano de Derechos Humanos, 2003

LEWIS, Anthony. Freedom for the thought that we hate: a biography of the First Amendment. New York: Basic Books, 2007

MACKINNON, Catherine. Are women human? And other international dialogues. Cambridge: Harvard University Press, 2007 . Only words. Cambridge: Harvard University Press, 1996

MEYER-PFLUG, Samantha Ribeiro. Liberdade de expressão e discurso do ódio. Sāo Paulo: Editora Revista dos Tribunais, 2009

MILL, John Stuart. On liberty. New York: Dover Publications Inc., 2002

SARMENTO, Daniel. A liberdade de expressão e o problema do hate speech. Revista de Direito do Estado. Rio de Janeiro: Renovar, 2006

SCHAUER, Frederick. Facts and the First Amendment. UCLA Law Review, n. 897,2010

SILVA, José Afonso da. Curso de Direito Constitucional positivo. $32^{\mathrm{a}}$ ed. São Paulo: Malheiros Editores, 2009

STF, HC n. 82.424-2/RS, Rel. Ministro Moreira Alves, Brasília, 17 set. 2003

Supreme Court of the United States. Smith v. Collin, 439 U.S. 916. (1978). Sentença em 16 de outubro de 1978

United States Court of Appeals, Seventh Circuit. Smith v. Collin [578 F.2d 1197]. Sentença em 22 de maio de 1978.

United States District Court, N.D. Illinois. Smith v. Collin [447 F.Supp. 676]. Sentença em 23 de fevereiro de 1978

VANEIGEM, Raoul. Nada é sagrado, tudo pode ser dito: reflexões sobre a liberdade de expressão. São Paulo: Parábola Editorial, 2004 